\title{
Characterization of the dsDNA prophage sequences in the genome of Neisseria gonorrhoeae and visualization of productive bacteriophage
}

\author{
Andrzej Piekarowicz ${ }^{\dagger 1}$, Aneta Kłyż ${ }^{1}$, Michał Majchrzak ${ }^{1}$, Monika Adamczyk- \\ Popławska ${ }^{1}$, Timothy K Maugel ${ }^{3}$ and Daniel C Stein*2
}

Address: ${ }^{1}$ Institute of Microbiology, Warsaw University, Miecznikowa 1, 02-096 Warsaw, Poland, ${ }^{2}$ Department of Cell Biology and Molecular Biology, University of Maryland, College Park, MD, 20742, USA and ${ }^{3}$ Laboratory of Biological Ultrastructure, University of Maryland, College Park, MD, 20742, USA

Email: Andrzej Piekarowicz - anpiek@biol.uw.edu.pl; Aneta Kłyż - anpiek@biol.uw.edu.pl; Michał Majchrzak - misieq@biol.uw.edu.pl; Monika Adamczyk-Popławska - poplawa@biol.uw.edu.pl; Timothy K Maugel - tmaugel@umd.edu; Daniel C Stein* - dcstein@umd.edu

* Corresponding author †Equal contributors

Published: 5 July 2007

BMC Microbiology 2007, 7:66 doi:10.1/86/147|-2180-7-66
Received: 10 October 2006

Accepted: 5 July 2007

This article is available from: http://www.biomedcentral.com/I47I-2/80/7/66

(c) 2007 Piekarowicz et al; licensee BioMed Central Ltd.

This is an Open Access article distributed under the terms of the Creative Commons Attribution License (http://creativecommons.org/licenses/by/2.0), which permits unrestricted use, distribution, and reproduction in any medium, provided the original work is properly cited.

\begin{abstract}
Background: Bioinformatic analysis of the genome sequence of Neisseria gonorrhoeae revealed the presence of nine probable prophage islands. The distribution, conservation and function of many of these sequences, and their ability to produce bacteriophage particles are unknown.
\end{abstract}

Results: Our analysis of the genomic sequence of FAI090 identified five genomic regions (NgoФI - 5) that are related to dsDNA lysogenic phage. The genetic content of the dsDNA prophage sequences were examined in detail and found to contain blocks of genes encoding for proteins homologous to proteins responsible for phage DNA replication, structural proteins and proteins responsible for phage assembly. The DNA sequences from NgoФ1, Ngo 22 and NgoФ3 contain some significant regions of identity. A unique region of $\mathrm{Ngo} \Phi 2$ showed very high similarity with the Pseudomonas aeruginosa generalized transducing phage FI 16. Comparative analysis at the nucleotide and protein levels suggests that the sequences of Ngo $\Phi 1$ and Ngo $\Phi 2$ encode functionally active phages, while NgoФ3, Ngo 44 and Ngo $\Phi 5$ encode incomplete genomes. Expression of the Ngo $\Phi$ I and Ngo $\Phi 2$ repressors in Escherichia coli inhibit the growth of $E$. coli and the propagation of phage $\lambda$. The Ngo $\Phi 2$ repressor was able to inhibit transcription of $N$. gonorrhoeae genes and Haemophilus influenzae HPI phage promoters. The holin gene of NgoФI (identical to that encoded by NgoФ2), when expressed in $E$. coli, could serve as substitute for the phage $\lambda s$ gene. We were able to detect the presence of the DNA derived from NgoФI in the cultures of $N$. gonorrhoeae. Electron microscopy analysis of culture supernatants revealed the presence of multiple forms of bacteriophage particles.

Conclusion: These data suggest that the genes similar to dsDNA lysogenic phage present in the gonococcus are generally conserved in this pathogen and that they are able to regulate the expression of other neisserial genes. Since phage particles were only present in culture supernatants after induction with mitomycin $C$, it indicates that the gonococcus also regulates the expression of bacteriophage genes. 


\section{Background}

The sequencing of bacterial genomes has revealed the presence of integrated viral genomes (prophages) in most of the sequenced bacterial genomes [1-3] Prophage DNA sequences can constitute up to $10-20 \%$ of the bacterial genome and are major contributors for differences between individual species [3]. Prophage gene expression may influence the pathogenicity or the general fitness of the bacterium $[4,5]$. The list of genes regulated by bacteriophage is very long and represents a broad group of genes (For review, see Brüsow et al. [1,6]).

Analysis of prophage DNA suggests that integration into bacterial genomes can lead to changes including inactivating point mutations, genome rearrangements, modular exchanges, invasion by further mobile DNA elements, and massive DNA deletion $[2,6,7]$. Bacteriophage have been described that can produce plaques on certain commensal Neisseria [8-10]. Bacteriophage able to propagate in $N$. meningitidis have been identified, but they were not able to propagate on other Neisseria strains [11]. Similarly, the presence of autoplaquing in $N$. gonorrhoeae was observed but no phage propagation was seen [12].

DNA sequence analysis has identified prophage DNA sequences in the genomes of most bacteria. In N. meningitidis, they belong to two groups of phages. The presence of the $\mathrm{Mu}$-like prophage sequences was detected in the genomes of serogroup A strains of the epidemic subgroups I, III, IV-1 and VI of N. meningitidis [13-15]. Two additional Mu-like sequences were found in N. meningitidis serotype A [14]. A 39.3-kb region named as Pnm1 [13] looks as if it could also encode for a functional bacteriophage. A sequence homologous to Pnm1 was found in the genome of serogroup B N. meningitidis but not in genome of $N$. gonorrhoeae FA1090 [15]. The second group consists of filamentous prophage sequences homologous to $\mathrm{f} 1$ and СТХФ [16]. These prophages can excise, albeit with very low frequency, from the bacterial genome resulting in the production of biologically active phages [16].

In this paper we describe properties of prophage sequences present in $N$. gonorrhoeae genomes (NgoФ1 5) that all belong to dsDNA tailed group of bacteriophage. We show the biological activity of some of the prophage genes and the presence of the prophage DNA sequences in bacterial cultures. We further demonstrate the production of phage particles by gonococci. However, we were unable to demonstrate the production of plaques on any of the $N$. gonorrhoeae or on non pathogenic Neisseria strains tested.

\section{Results \\ Overall genetic structure of $\mathrm{Ngo} \Phi \mathrm{I}-\mathrm{Ngo} \Phi 5$ prophages}

Annotation of the coding sequences in the published genomic sequence of $N$. gonorrhoeae strain FA1090 [17] indicated that the gonococcus possesses 5 genomic regions that encode proteins with significant homology to proteins found in dsDNA bacteriophages. The location of the coding sequences of each of these genomic regions is described in table 2. We have designated these regions NgoФ1 to NgoФ5. We determined the overall distribution of guanine and cytosine residues in the gonococcal chromosome, determined the $\mathrm{G}+\mathrm{C}$ content by the windows sliding method for the putative prophage sequences, and identified their location on the gonococcal chromosome (See Fig. 1). Four of the prophage sequences have a higher $\mathrm{G}+\mathrm{C}$ content $(54-57 \%)$ while one (NgoФ4) has a lower $\mathrm{G}+\mathrm{C}$ content $(49 \%)$ as compare to an average $\mathrm{G}+\mathrm{C}$ content of $52.5 \%$ of $N$. gonorrhoeae genomic DNA. The location of each of the prophage coding sequences, while differing in $\mathrm{G}+\mathrm{C}$ content from the overall gonococcal chromosome, did not appear to be significantly different from the regions immediately adjacent to the prophage sequences. We analyzed the codon usage for the predicted ORFs of the prophage regions and compared them to the overall codon usage of the gonococcus. While some of the ORFs appeared to have significant codon usage differences, the variations were no greater than what was obtained when we generated a codon usage profile for the two beta subunits of RNA polymerase (data not shown). This observation prevented us from drawing any evolutionary inferences, based on base content or codon usage.

The five prophage sequences homologous with dsDNA phages ranged from 8614 bp to 42927 bp. BLAST and MegaBlast (nucleic acid) searches performed against the non-redundant database did not shown homology to any DNA sequences, except to very small regions in the genomes of $N$. meningitidis and Pseudomonas aeruginosa phage F116. This analysis also showed that the two, almost identical (with about $95 \%$ of identity) blocks of DNA, (of total length about $11000 \mathrm{bp}$ ) present at the left hand end of Ngo $\Phi 1$ are present in the sequence of NgoФ2 and one of them is also present in the sequence of NgoФ3 (Fig. 2). These blocks include genes whose predicted function would be either regulatory or structural. The genome of NgoФ3 is divided into two parts due to the presence of the inserted genomic sequence of a filamentous phage (Nf4-NgoФ6). The NgoФ3 prophage sequence was probably derived from NgoФ1 or NgoФ2. The sequences of Ngo $\Phi 4$ and NgoФ5 are not homologous and do not share any homology with any of the other phages.

We analyzed the protein coding sequences (CDS) for all five putative prophage sequences. Putative ORFs greater than 40 amino acids were identified using a combination of CDS identification programs. The results of this analysis show that the identified prophage islands contain CDSs with striking amino acid similarities to known functional phage proteins (Table 3 ). The length and the coding 


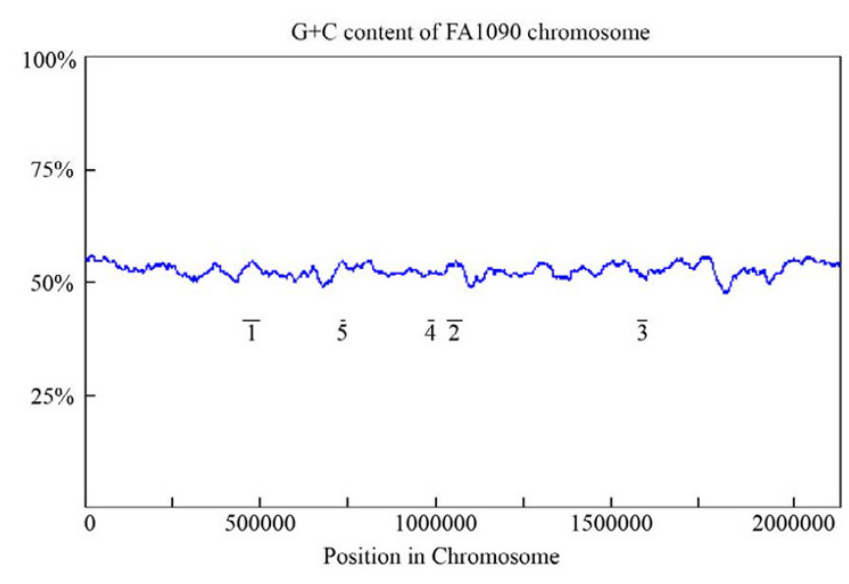

Figure I

G + C content of gonococcal chromosome. The position of the various prophage sequences in the gonococcal chromosome are shown as short black lines, labeled I through 5. These bars represent prophages Ngol-5 respectively.

capacity of genomic DNA of NgoФ1 and NgoФ2 suggest that they could represent biologically active prophages. We also noted the presence of four filamentous ssDNAlike prophage sequences that share very high homology to such sequences in the $N$. meningitidis genome (homology ranged from $90-97 \%$ identity, data not presented). Since the genomic organization of these phage have been described for a variety of neisserial stains $[16,18]$, we did not focus our studies on them.

\section{Modular genome organization of phage Ngo $\Phi$ I}

The DNA sequence of phage Ngo $\Phi 1$ contains 62 CDSs that we annotated as phage related genes (Fig. 2). A large number of the CDSs show significant homology to other known phage genes (Table 3). Some of the CDSs encode putative proteins with no current functional annotation. Based on available data, sequence similarity, and domain and motif searches, information indicating for modular organization of the genome was obtained. Both ends of the phage DNA encoded two bacteriophage P4-like integrases belonging to pfam 00589 family (NGO0462 and NGO0524) with no homology between either of them. The P4 integrase mediates integrative and site-specific recombination between two attachment sites, located on the phage genome and the bacterial chromosome. NGO0462, encoding the first of these integrases, is preceded by the sequence encoding serine tRNA (NGO0461) and a 151 bp noncoding region. Similarly, a noncoding region is also present downstream of the last phage gene (NGO0524). We were unable to identify any repetitive sequences at either end of the integrated phage DNA.
Analysis of the CDSs encoded by this phage allowed us to clearly identify two blocks of genes encoding structural and assembly proteins. The longer block spanning from NGO0494 to NGO0505 includes such genes as NGO0494 and NGO0495 which encode small and large terminase subunits respectively, NGO0496 which encodes phage portal protein and NGO0510, which encodes a phage tail protein. The smaller block of structural genes is located at the end of phage genome (NGO0522 and NGO0523) and encodes the tail protein. The remaining CDSs encode either proteins of unknown function or other structural proteins. It is interesting that gene NGO0509, which interrupts the larger block, belongs to the transcriptional regulator family of genes. The regulatory modules include one well defined region (NGO0474 to NGO0483) with NGO0479 encoding a protein similar to cI-like repressor protein. Two less defined regulatory modules are located in the region between NGO0515-0517 and in the region of NGO0464. The main regulatory module are predicted to encode not only cI repressor but also other proteins that show some homology to phage and cell transcriptional regulatory proteins, (NGO0474, NGO0477, and NGO0478), or the presence of a domain specific for regulatory protein (NGO0483). NGO0479 contains well defined helix-turnhelix motif (E value $6^{-4}$ ) between $\mathrm{I}^{30}$ and $\mathrm{F}^{75}$ and high scoring (E value $5^{-6}$ ) from $\mathrm{V}^{147}$ to $\mathrm{D}^{219}$ peptidase family S24. These motifs are present in DNA binding proteins, including the cro and cI proteins of phage lambda. NGO0477 also contained a helix-turn-helix motif (E value: $4^{-10}$ ).

The special control region includes two CDSs, NGO0516 and NGO0517, which encode PemK and PemI-like proteins. The pemI-pemK system is an addiction module present on plasmid R100 that helps to maintain the plasmid by post-segregational killing of $E$. coli cells that have lost the plasmid $[19,20]$. PemK, the toxin encoded by the pemI-pemK addiction module, inhibits protein synthesis in an E. coli cell-free system, whereas the addition of PemI, the antitoxin against PemK, allows for the resumption of protein synthesis. These systems are also known to operate by stabilizing the presence of autonomously replicating prophages, like P1 [21].

The third module includes genes that play a role in the replication of the phage genome. This module includes two well defined CDSs, NGO0484 and NGO0485, and a third CDS, NGO0469, located to left end of the genome. NGO0485 encodes a helicase with high homology to the phage P1 gene ban or gp12 of Salmonella typhimurium bacteriophage ST64T (Table 3). All these proteins belong to pfam DnaB, DnaB-C family. NGO0484 shows high homology to a DNA replication protein of bacteriophage AAphi23 as well as other phages. Finally, the NGO0469 probably encodes the primase. 


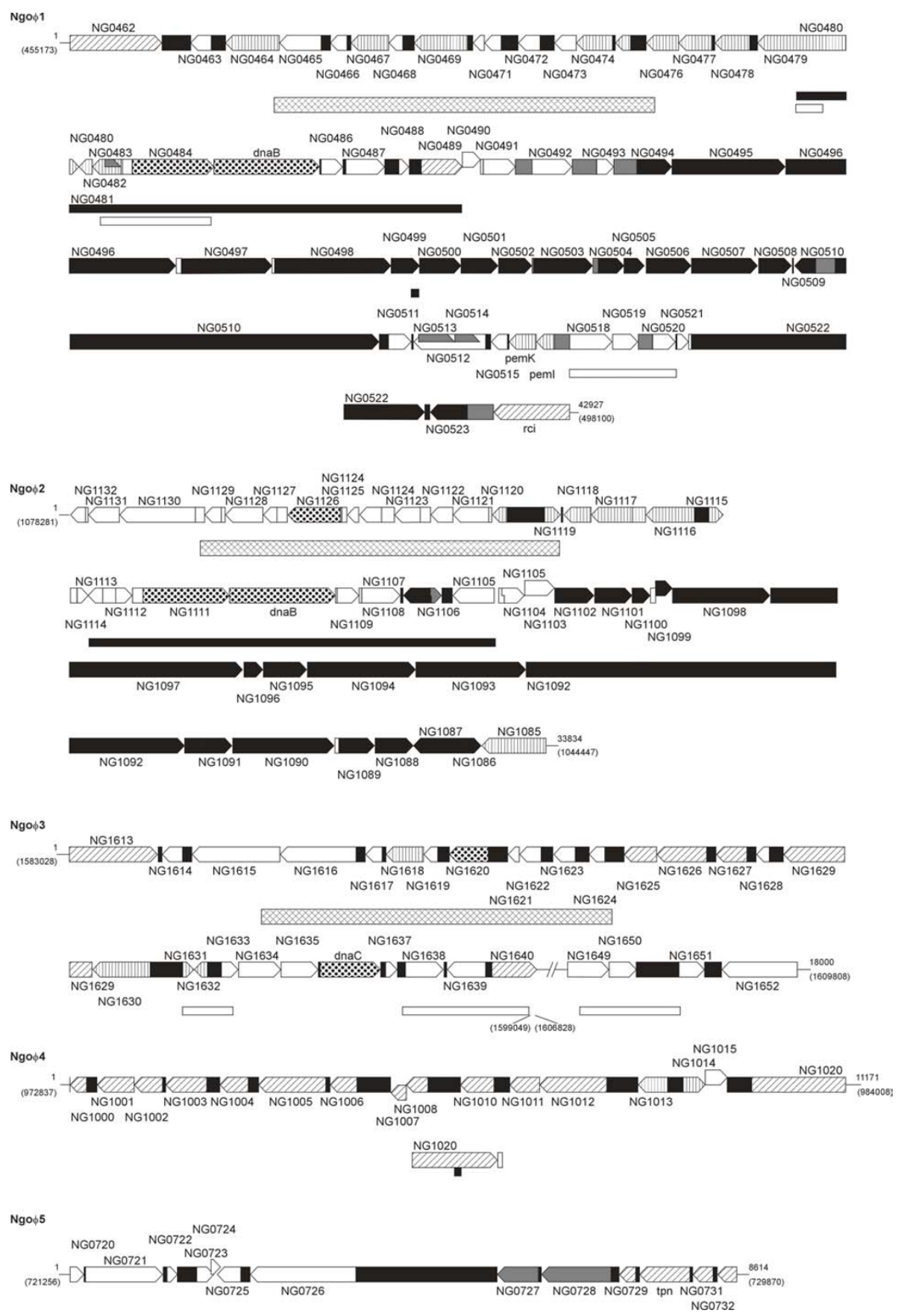

Figure 2

Genomic organization of $\mathbf{N g o} \phi \mathbf{I}-\mathbf{N g o} \phi 5$ prophages in $\mathbf{N}$. gonorrhoeae. Arrows oriented in the direction of transcription represent CDSs or genes. Arrows with black dots represents the replication module, solid arrows represent the structural module, and the arrows with vertical lines represent the CDSs encoding the repressors and other regulatory genes. The open arrows represent the CDSs with unknown function. Arrows with cross-hatching represent integrases. The filled rectangles (black or gray) represent putative non coding regions. The regions homologous for NgoФI, Ngo 22 and NgoФ3 are shown as rectangles with cross-hatched regions. The regions homologous for Ngo $\Phi 1$ and Ngo $\Phi 2$ are shown as solid black rectangles while those homologous for $\mathrm{Ngo} \Phi \mathrm{I}$ and $\mathrm{Ngo} \Phi 3$ as white open rectangles. The broken line representing the genome of NgoФ3 (between CDSs 1640 and 1649) shows the site where the integrity of this genome is broken by the presence of part of the Ngo $\Phi 7$ genome). The numbers at the beginning and end of each phage show the lengths of prophage genomes (in bp) while the numbers in parenthesis show the positions of prophages in N. gonorrhoeae FAl090 chromosome. 
Table 2: Localization of the prophage islands on the genome sequence of $N$. gonorrhoeae FA 1090

\begin{tabular}{|c|c|c|c|c|}
\hline Prophage & Sequence coordinates ${ }^{a}$ & Length of the DNA sequence (bp) & CDS annotations (Acc. No AE004969) & Number of CDS\# \\
\hline \multicolumn{5}{|c|}{ ds DNA prophage sequences } \\
\hline NgoФ। & $455173-498100$ & 42927 & NGO0462-NGO0524 & 63 \\
\hline NgoФ2 & $1044447-1078281$ & 33834 & NGOI085-NGOII32 & 48 \\
\hline NgoФ3 & $\begin{array}{l}1583028-1599049 \\
1606828-1609808\end{array}$ & $\begin{array}{l}16021 \\
2980\end{array}$ & $\begin{array}{l}\text { NGOI6I3-NGOI640 } \\
\text { NGOI649-NGOI652 }\end{array}$ & 284 \\
\hline NgoФ4 & $972837-984008$ & 11171 & NGOI000-NGOI020 & 21 \\
\hline NgoФ5 & $721256-729870$ & 8614 & NGO0720-NGO0732 & 13 \\
\hline \multicolumn{5}{|c|}{ Filamentous ss DNA prophage sequences } \\
\hline NgoФ6 & $1080185-1088420$ & 8235 & NGOII37-NGOII46 & 13 \\
\hline NgoФ7 & $1215967-1223383$ & 7416 & NGOI 262 - NGOI 270 & 12 \\
\hline NgoФ8 & $1103017-1109444$ & 6427 & NGOII64 - NGOII70 & 8 \\
\hline Ngo $\Phi 9$ & $1599378-1607537^{*}$ & 7159 & NGOI64I - NGOI648 & 9 \\
\hline
\end{tabular}

aCoordinates are relative to the DNA sequence contained at GenBank Acc. No AE004969.

\# Number ofCDSdetermined in this paper for NgoФ6, NgoФ7, NgoФ8 and NgoФ9 is higher than cited by National Center for Biotechnology Information.

Note that the sequence of Ngo $\Phi 9$ is inserted within the sequence of Ngo $\Phi 3$

\section{Modular genome organization of phage $\mathrm{Ngo} \Phi 2$}

The sequence of NgoФ2 shows a modular organization and some regions possess almost 100\% homology with the DNA sequence of Ngo $\Phi 1$. The overall orientation of the DNA sequence and the localization of the genes in NgoФ2 are in the opposite orientation relative to NgoФ1. We were also unable to find repetitive DNA sequences at the end of the DNA sequence of the CDSs encoding the integrases (Fig. 2, Table 4). The regions of homology cover the sequences from the left end of both phages (except of first $1600 \mathrm{bp}$ ) up to the beginning of the gene encoding presumptive recombination module, and the module of the structural genes, with the exception of the module controlling the transcription (Fig. 2) in NgoФ1 (NGO0475 to NGO0480). This suggests that while these two DNA sequences represent two different phages, they share homology between genes encoding the replication machinery but do not share homology between the genes responsible for the control of gene expression, maintenance of the state of lysogeny (the genes encoding presumptive repressors; NGO0479 in NgoФ1 and NGO1116 in NgoФ2), in the recombination module and in the structural modules of both phages. The putative repressor (NGO1116) contains a well defined helix-turn-helix motif (E value $8^{-04}$ ) between $\mathrm{M}^{1}$ and $\mathrm{L}^{40}$ and high scoring (E value $7^{-04}$ ) peptidase family S24 motif from $\mathrm{P}^{123}$ to $\mathrm{D}^{200}$. However, the putative antirepressor (NGO1085) is located at the end of the genome, a long distance from the repressor. NGO1085 shows high homology to some of the phage antirepressors, like that of bacteriophage Aaphi23 or E. coli prophage CP-933N.

The structural and assembly module, extending from NGO1105 to NGO1086, contains the genes encoding the large and small terminase proteins (NGO01098 and NGO01101 respectively) and the portal protein (NGO01097). The structural module contains one very large protein (1977 aa) encoded by NGO1092, whose Cterminal part shows some homology to DNA methyltransferases. NGO1085 would seem to encode a protein with homology to phage antirepressors. While the structural module of NgoФ2 (NGO1102 to NGO1186) shows high identity with $P$. aeruginosa phage F116, the structural block of Ngo $\Phi 1$ does not show high identity with any particular phage sequence.

\section{Modular genome organization of phage $\mathbf{N g o} \Phi 3$}

The DNA sequence of NgoФ3 is much smaller than NgoФ1 and NgoФ2 and is disrupted by the insertion of the DNA sequence of ssDNA phage Ngo 99 . The first part of the sequence ( $16021 \mathrm{bp}$ ) encodes 28 CDSs while the second part of (2980 bp) encodes only four CDSs. The genome sequence starting with NGO1613, encodes a P22-like integrase but without homology to the integrase encoded by NgoФ1. The majority of the DNA sequence shows homology to DNA sequence of NgoФ1 and NgoФ2. Two regions without homology include: (i) NGO0475 - NGO0409 responsible for the maintenance of lysogenic state (encoding a repressor) and (ii) NGO0482-NGO0487, genes responsible for DNA replication. There is also lack of the NgoФ1 DNA region encoding PemK-PemI proteins. However, the most important difference between the genomic sequences of NgoФ3 and Ngo $\Phi 1$ and NgoФ2 is the lack of CDSs encoding the structural protein (structural-assembly module). The second part of the genome of NgoФ3 encodes the antirepressor protein (NGO1652) which is identical with NGO1085 encoded by the phage NgoФ2. 
Table 3: Properties of the NgoФI CDS' sequences

\begin{tabular}{|c|c|c|c|c|c|c|}
\hline \multirow[t]{2}{*}{ NgoФI CDSs } & \multirow[t]{2}{*}{ Genome position } & \multirow[t]{2}{*}{ Length (aa) } & \multirow[t]{2}{*}{ Putative function } & \multirow{2}{*}{$\begin{array}{l}\text { Significant matches to proteins in GenBank, scores represent filtered } \\
\text { BLASTP, \% identities, over stated number of amino acid) }\end{array}$} & \multicolumn{2}{|c|}{ Identity with CDSs } \\
\hline & & & & & Ngo $Ф 2$ & NgoФ3 \\
\hline NGO0462 & $455173-456369$ & 398 & phage integrase & $\begin{array}{l}\text { VC0847 [Vibrio cholerae] 3I, } 51 \% \text { on } 406 \text {, Int A E. coli KI2 32, } 51 \% \text { on } \\
412\end{array}$ & & \\
\hline NGO0463 & $456725-456994$ & 89 & NS* & & & \\
\hline NGO0464 & $457 \mid 89-457872$ & 227 & hypothetical protein & B3 CDS5 [Bacteriophage B3] 29, 46\% on 227 & 1130,1131 & $2 e+07$ \\
\hline NGO0465 & $457883-458419$ & 178 & NS & & & \\
\hline NGO0466 & $458530-458745$ & 71 & NS & & 1129 & 1617 \\
\hline NGO0467 & $458797-459288$ & 163 & hypothetical protein & $\begin{array}{l}\text { CDS8 [Streptococcus phage } \Phi-O \mid 205] \text { (pfam SiphoGp } 35,56 \% \text { on I } 44 \text {, } \\
\text { CDSI } 57 \text { [Streptococcus } 157 \text { family) Thermophilus phage Sfi2 } 1] 31 \text {, } 51 \% \text { on } \\
160\end{array}$ & 1128 & 1618 \\
\hline NGO0468 & $459285-459467$ & 60 & NS & & 1127 & 1619 \\
\hline NGO0469 & $459607-460293$ & 228 & replication initiation & $\begin{array}{l}\text { BBTVs Igp I [Banana bunchy top virus] replication protein } 26,43 \% \text { on } \\
109 \text { primase A2p38 [Lactobacillus casei phage A2] 32, } 44 \% \text { on } 87\end{array}$ & 1126 & 1620 \\
\hline NGO0470 & $460362-460523$ & 53 & NS & & 1125 & 1621 \\
\hline NGO047I & $460520-460735$ & 71 & hypothetical protein & $\begin{array}{l}\text { NMB0904 [N. meningitidis MC58] } 45,63 \% \text { on } 61, \text { gP30 [Burkholderia } \\
\text { cepacia phage Bcep22] 37, 54\% on } 48\end{array}$ & 1124 & 1622 \\
\hline NGO0472 & $460949-461236$ & 95 & NS & & 1123 & 1623 \\
\hline NGO0473 & $46|422-46| 697$ & 91 & NS & & 1122 & \\
\hline NGO0474 & $461694-462170$ & 158 & $\begin{array}{l}\text { transcriptional } \\
\text { regulator }\end{array}$ & $\operatorname{IrgB}[V$. cholerae strain NI696I serogroup OI] $26,62 \%$ on 50 & 1121 & \\
\hline NGO0475 & $462203-462403$ & 66 & NS & & 1120 & 1624 \\
\hline NGO0476 & $462601-463014$ & 137 & NS & & & \\
\hline NGO0477 & $463011-463448$ & 145 & transcriptional & $\begin{array}{l}\text { EFI } 886 \text { [Enterococcus faecalis (pfam HTH } 3 \text { family) regulator V583] 45, } \\
70 \% \text { on } 44, \mathrm{NMBI} 204 \text { [N. meningitidis MC58] 32, 59\% on } 62\end{array}$ & & \\
\hline NGO0478 & $463489-463926$ & 145 & NS & & & \\
\hline NGO0479 & $464039-464755$ & 238 & repressor protein cl & $\begin{array}{l}\text { cl [Salmonella typhimurium (pfam peptidase I } 630 \text { phage TI } 04] \text { 29, } 52 \% \\
\text { on } 222 \text { S24family), HK022 p43 [Enterobacteria phage HK022] } 30,49 \% \text { on } \\
223 \text { [Pseudomonas phage D3] 26, 42\% on } 221\end{array}$ & & 1630 \\
\hline NGO0480 & $465 \mid 40-465295$ & 51 & NS & & 1114 & 1631 \\
\hline NGO048I & $465272-465460$ & 62 & NS & & 1113 & 1632 \\
\hline NGO0482 & $465465-465827$ & 120 & NS & & & \\
\hline NGO0483 & $46633-465860$ & 75 & hypothetical protein & Bcep22p22 [B. cepacia phage Bcep22] 32, 52\% on 71 & 1112 & 1633 \\
\hline NGO0484 & $465978-467042$ & 354 & $\begin{array}{l}\text { DNA replication } \\
\text { protein }\end{array}$ & $\begin{array}{l}\text { [Phage Aaphi23] } 33,45 \% \text { on } 342 \text { Gp54 [Phage HK97] 26, } 42 \% \text { on } 123 \\
\text { [Enterobacteria phage P22] } 24,17 \% \text { on } 125\end{array}$ & 1111 & \\
\hline NGO0485 & $467039-468400$ & 453 & $\begin{array}{l}\text { replicative DNA } \\
\text { helicase }\end{array}$ & $\begin{array}{l}\text { (pfam DnaB family, DnaB-C family) [Enterobacteria phage PI] } 34,53 \% \text { on } \\
446, \text { CDS74 [Pseudomonas phage D3 ] 32, 55\% on } 430\end{array}$ & 1110 & \\
\hline NGO0486 & $4684|7-46870|$ & 94 & NS & & 1109 & \\
\hline NGO0487 & $468740-469234$ & 164 & hypothetical protein & SAI787 [Staphylococcus phage phiN3I5] 4I, 5I\% on 58 & 1108 & 1638 \\
\hline NGO0488 & $4694 \mid I-469560$ & 49 & NS & & 1106 & \\
\hline NGO0489 & $469696-470241$ & 181 & $\begin{array}{l}\text { Endodeoxyribo- } \\
\text { nuclease }\end{array}$ & $\begin{array}{l}\text { rus [Phage } 82 \text { ] } 34,47 \% \text { on } 102 \text { (pfamRusA family) RUS Sb } 45 \text { [S. } \\
\text { typhimurium phage ST64B ] 3I, } 44 \% \text { on II 3, rus [Phage HK620] 30, } 47 \% \\
\text { on } 96\end{array}$ & & 1640 \\
\hline NGO0490 & $470231-470464$ & 77 & hypothetical protein & gpl8 [B. cepacia phage Bcep22] 46, 58\% on 41 & & \\
\hline NGO049I & 470508-4709|5 & 135 & NS & & & \\
\hline NGO0492 & $47 \mid$ I 38-47| 644 & 168 & NS & & & \\
\hline
\end{tabular}


Table 3: Properties of the NgoФI CDS' sequences (Continued)

\begin{tabular}{|c|c|c|c|c|c|c|}
\hline NGO0493 & $471965-472186$ & 73 & hypothetical protein & SfVP44 [Shigella flexneri phage V] $50,67 \%$ on 34 & & \\
\hline NGO0494 & $472479-472928$ & 149 & $\begin{array}{l}\text { terminase small } \\
\text { subunit }\end{array}$ & $\begin{array}{l}\text { f6pol [Enterobacteria phage Sf6] } 45,69 \% \text { on I22, } 3 \text { [Phage HK620] 45, } \\
69 \% \text { on I } 22\end{array}$ & & \\
\hline NGO0495 & $472990-474411$ & 473 & $\begin{array}{l}\text { terminase large } \\
\text { subunit }\end{array}$ & $\begin{array}{l}\text { TIp5324 [Enterobacteria phage TI] (COG } 24,42 \% \text { on } 505 \text {, TerL [Phage } \\
\text { terminase Aaphi23] 28, } 45 \% \text { on } 438,\end{array}$ & & \\
\hline NGO0496 & $474408-476555$ & 715 & phage portal protein & $\begin{array}{l}\text { gp34 [Phage phi-C3I] (pfam Phage Mu F family) } 25,43 \% \text { on } 254, \text { gp } 34 \\
\text { [Phage phiB 25], } 43 \% \text { on } 258\end{array}$ & & \\
\hline NGO0497 & $476623-477780$ & 385 & $\begin{array}{l}\text { protease structural } \\
\text { protein }\end{array}$ & $\begin{array}{l}\text { T5 I50 [Phage T5] 31, 48\% on } 137 \text { psiMl00p } 19 \text { [Methanothermobacter } \\
\text { wolfeii prophage psiMi00], } 46 \% \text { on } 140\end{array}$ & & \\
\hline NGO0498 & $477821-479320$ & 499 & hypothetical protein & 2 [Equine herpesvirus I] $23,30 \%$ on 18 & & \\
\hline NGO0499 & $479327-479689$ & 120 & NS & & & \\
\hline NGO0500 & $479692-480222$ & 176 & hypothetical protein & gP8 [Phage phiE I25] 30, 44\% on I25 & & \\
\hline NGO050I & $480370-480702$ & 110 & putative virion & $\begin{array}{l}\text { SO690 protein, prophage MuSo2, morphogenesis protein [Shewanella } \\
\text { oneidensis MR-1] } 47,60 \% \text { on } 53\end{array}$ & & \\
\hline NGO0502 & $480699-48 \mid I 27$ & 142 & NS & & & \\
\hline NGO0503 & $481153-481926$ & 257 & NS & & & \\
\hline NGO0504 & $481987-482316$ & 109 & hypothetical protein & PHG3 IpII protein [Aeromonas phage 3 I] $28,46 \%$ on 88 & & \\
\hline NGO0505 & $482328-482594$ & 88 & NS & & & \\
\hline NGO0506 & $482594-483193$ & 199 & hypothetical protein & gP83 [Phage phi JL00I] 25, $46 \%$ on 80 & & \\
\hline NGO0507 & $483190-484044$ & 284 & hypothetical protein & $\begin{array}{l}\text { gp84 [Phage phi JL00I] 42, 58\% on 103, D3I I 2p50 [Phage D3। I2] 32, } \\
47 \% \text { on } 50\end{array}$ & & \\
\hline NGO0508 & $484046-484477$ & 143 & hypothetical protein & $\begin{array}{l}\text { BMEII342 protein) (pfam06940, DUFI } 287 \text { [Brucella melitenis] 33, 47\% } \\
\text { on II9 }\end{array}$ & & \\
\hline NGO0509 & $484505-484789$ & 93 & unknown & $\begin{array}{l}\text { CDSI I } 4 \text { [Pseudomonas phage phiKZ } 43,60 \% \text { on } 81 \text { transcriptional } \\
\text { regulator PP0276 [P. putida KT2440] Cro/cl family } 39,65 \% \text { on } 63\end{array}$ & & \\
\hline NGO05I0 & $485026-489|7|$ & $138 \mid$ & hypothetical protein & $\begin{array}{l}\text { gp86 [Phage phi JLO0I] } 22,39 \% \text { on } 459 \text { CDS97 [Lactobacillus plantarum } \\
\text { phage LP65] 26, 42\% on } 173 \text { putative phage tail protein HCM2.005c } \\
\text { protein [S. enterica] } 27,44 \% \text { on } 180\end{array}$ & & \\
\hline NGO05II & $489283-489588$ & 101 & NS & & & \\
\hline NGO05I2 & $489593-490528$ & 311 & NS & & & \\
\hline NGO05I3 & $489659-490129$ & 156 & NS & & & \\
\hline NGO0514 & $490130-490462$ & 110 & NS & & & \\
\hline NGO05I5 & $490591-490824$ & 77 & NS & & & \\
\hline NGO05I6 & $490832-491179$ & 115 & PemK & & & \\
\hline NGO0517 & $491179-491415$ & 78 & Peml & (pfam SpoVT AbrB family) & & \\
\hline NGO05I8 & $491622-492161$ & 114 & hypothetical protein & NMB09 12 protein [N. meningitidis MC58] 32, 45\% on 53 & & 1649 \\
\hline NGO0519 & $492162-492506$ & 120 & NS & & & 1650 \\
\hline NGO0520 & $492680-492990$ & 103 & NS & & & \\
\hline NGO052I & $493004-493153$ & 49 & hypothetical protein & NMB0989 protein [N. meningitidis MC58] $55,61 \%$ on 47 & & \\
\hline NGO0522 & $493183-496230$ & 1015 & tail length tape & $\begin{array}{l}\text { JL00p82 [Phage phi JL00I measure protein } 29,50 \% \text { on } 407 \text { putative tail } \\
\text { component [Z6034] protein cryptic prophage CP-933P [E. coli] } 27,47 \% \\
\text { on } 259\end{array}$ & & \\
\hline NGO0523 & $496290-496769$ & 159 & hypothetical protein & NMB0899 [N. meningitidis MC58] 100, $100 \%$ on 118 & 1095 & \\
\hline NGO0524 & $497 \mid 11-498100$ & 329 & integrase & $\begin{array}{l}\text { [Haemophilus influenzae R2866] (pfam phage integrase family } 49,62 \% \text { on } \\
200\end{array}$ & & 1613 \\
\hline
\end{tabular}

\footnotetext{
* No significant homology with any gene in the database
} 
Table 4: Properties of the NgoФ2 CDS' sequences

\begin{tabular}{|c|c|c|c|c|}
\hline NgoФ2 CDSs & Genome position & Length (aa) & Putative function & $\begin{array}{l}\text { Significant matches to proteins in GenBank (Scores represent filtered BLASTP \% } \\
\text { identities over stated number of amino acid) CDSs }\end{array}$ \\
\hline NGOI085 & $1044447-1045292$ & 281 & $\begin{array}{l}\text { prophage antirepressor protein } \\
933 \mathrm{~N}], 37,56 \% \text { on } 20\end{array}$ & $\begin{array}{l}\text { Ant [Phage Aaphi23], } 41,56 \% \text { on } 258 \text { (pfam02498, Bro } N \text { family) [E. coli prop } \\
\text { CP933N], 37, 56\% on } 20\end{array}$ \\
\hline NGOI087 & $1045494-1046174$ & 226 & NS & \\
\hline NGOI088 & $1046153-1046638$ & 161 & hypothetical protein & FII6p45 [P. aeruginosa phage $\mathrm{FII6}] 31,42 \%$ on 148 \\
\hline NGOI089 & $1046644-1047 \mid 1$ & 157 & phage structural protein & FII6p44 [P. aeruginosa phage FII6] $42 \%$ on 140 \\
\hline NGOI090 & $1047173-1048468$ & 431 & phage structural protein & FII6p43 [P. aeruginosa phage $\mathrm{FII}] 56,72 \%$ on 415 \\
\hline NGOI09I & $1048489-1048887$ & 132 & hypothetical protein & FII6p42 [P. aeruginosa phage $\mathrm{FII} 6] 34,49 \%$ on $14 \mathrm{I}$ \\
\hline NGOI092 & $1049094-1055027$ & 1977 & possible DNA methylase & [Sinorhizobium meliloti phage PBC5] 33, 52\% on 584 \\
\hline NGOI093 & $1055027-1056445$ & 472 & NS & [S. meliloti phage PBC5] 33, 52\% on 584 hypothetical protein FII 6 p60 \\
\hline NGOI094 & $1056442-1057638$ & 398 & NS & \\
\hline NGOI096 & $1058422-1058637$ & 71 & NS & \\
\hline NGOI097 & $1058674-106026$ & 750 & phage portal protein & FII6p40 [P. aeruginosa phage $\mathrm{FII}] 58,71 \%$ on 756 \\
\hline NGOI098 & $1060926-1062200$ & 424 & $\begin{array}{l}\text { phage terminase large subunit } \\
\text { Terminase } 3 \text { family }\end{array}$ & $\begin{array}{l}\text { ZMO } 0379 \text { [Zymomonas mobilis subsp.mobilis ZM4]phage terminase large subunit } 35 \text {, } \\
50 \% \text { on } 397\end{array}$ \\
\hline NGOI099 & $1062181-1062423$ & 80 & NS & [H. influenzae RdKW20] 44, $67 \%$ on 168 \\
\hline NGOIIO0 & $1062478-1062720$ & 80 & $\begin{array}{l}\text { prophage terminase small } \\
\text { subunit }\end{array}$ & STY 1046 [S. enterica subsp. enterica serovar Typhi] small subunit 33, 57\% on 45 \\
\hline NGOIIOI & $1062720-1063034$ & 104 & hypothetical protein & FII6p37 [P. aeruginosa phage $\mathrm{FII} 6] 38,59 \%$ on $8 \mathrm{I}$ \\
\hline NGOII02 & $1063207-1063725$ & 172 & $\begin{array}{l}\text { endonuclease of the } \mathrm{HNH} \\
\text { family }\end{array}$ & $\begin{array}{l}\text { I7R [Xanthomonas oryzae phage endonuclease Xp I0] } 41,53 \% \text { on } 167 \text { [S. thermophilus } \\
\text { phage ST3] } 47,55 \% \text { on } 85\end{array}$ \\
\hline NGOIIO3 & $1063716-1064099$ & 127 & protein Nin B & $\begin{array}{l}\text { HK022 p } 48 \text { [Enterobacteria phage HK022]30, 50\% on I2I, } 933 \mathrm{Wp} 33 \text { [Phage } 933 \mathrm{~W}] \\
27,49 \% \text { on } 99\end{array}$ \\
\hline NGOII 04 & $1064096-1064401$ & 101 & hypothetical protein & $\begin{array}{l}\text { FII } 6 \text { p } 35 \text { [P. aeruginosa FI I } 6] 42,57 \% \text { on } 98 \text { pfam DUF I } 364 \text { CDS- } 136 \text { [S. typhimurium } \\
\text { phage ST64T] } 53,66 \% \text { on } 30\end{array}$ \\
\hline NGOII 05 & $1064373-1064993$ & 206 & NS & \\
\hline NGOII07 & $1065246-10656 \mid 4$ & 122 & hypothetical protein & NMBIII6 [N. meningitidis] $88,96 \%$ on 27 \\
\hline NGOIII5 & $1069893-107008 \mid$ & 62 & NS & \\
\hline NGOIII6 & $1070260-1070907$ & 215 & transcriptional regulator & $\begin{array}{l}\text { NMB0910 [N. meningitidis regulator MC58] 83, 87\% on } 215, \mathrm{FII} 6 \mathrm{p} 29 \text { [P. aeruginosa } \\
\text { phage FII } 6] 39,54 \% \text { on } 157 \text { putative Cl protein cl [Phage Aaphi23]37, } 54 \% \text { on I9I, cl } \\
{[\text { Pseudomonas phage D3] } 30,44 \% \text { on } 218}\end{array}$ \\
\hline NGOIII7 & $1071067-1071606$ & 179 & hypothetical protein & $\begin{array}{l}\text { CDS2I [Phage bIL3II] GepA [phage-like] 37, 53\% on 135, SpyM3_I207 [S. pyogenes } \\
\text { phage } 315.4] 40,66 \% \text { on } 71\end{array}$ \\
\hline NGOIII8 & $1071607-1071966$ & 119 & NS & \\
\hline NGOIII9 & $107 \mid 983-1072201$ & 72 & NS & \\
\hline NGOII32 & $|078087-| 07828 \mid$ & 64 & hypothetical protein & 33 [Enterobacteria phage epsilon I5] $68 \%$ on 44 \\
\hline
\end{tabular}

\section{Modular genome organization of phages Ngo $\Phi 4$ and Ngo $\Phi 5$}

Phage DNA sequences corresponding to NgoФ4 and NgoФ5 (Fig. 2) do not share any homology to each other, or with NgoФ1, NgoФ2 and NgoФ3. Analysis of the homology of the CDSs encoded by these two sequences indicates that neither of them represents a complete phage genome (see Tables 5 and 6 ). The DNA sequence of Ngo $\Phi 4$ contains the genes encoding only the presumptive proteins engaged in the recombination, control of transcription and integration of DNA. NGO1000 and NGO1001 contain motifs typically characteristic for the RecBC family exonuclease protein, while NGO1020 contains the core domain characteristic for pfam 00665, Rve integrase. This family of genes is responsible for integration of the viral genome into the host chromosome. NGO1007 encodes protein with high homology to the transcription regulator proteins encoded by several phages, among them the Stx converting phages.

Among the CDSs encoded by the DNA sequence of NgoФ5 are ones that show high homology to structural and assembly proteins of different phages (see Table 7) but lack such homology to the small and large terminase subunits and the portal proteins. At the end of DNA sequence are genes encoding a putative repressor and transposase. The organization of these genes resemble the pyocin R2 and F2 gene cluster present in $P$ aeruginosa, which are phage tails that have been evolutionarily specialized as bacteriocins [22].

\section{Distribution of the dsDNA prophage sequences among the N. gonorrhoeae strains}

In $N$. meningitidis the phages homologous to ssDNA phages are present predominantly in the hypervirulent isolates [16]. On the other hand, the Mu-like prophage sequences are present in all N. meningitidis strains [15]. We tested for the presence of the dsDNA prophage sequences in the chromosome of $N$. gonorrhoeae FA1090 and other Neisseria strains by the formation of the PCR products specific for the NgoФ1 and NgoФ2 prophages CDSs encoding the large terminase subunit, holin and the repressor of Ngo $\Phi 2$ prophage. The results presented in Fig. 3 indicate that the amplicons obtained from the four $N$. gonorrhoeae strains tested were of the predicted molecular mass as the PCR amplicon generated from strain FA1090 suggesting that in all cases the same gene was present. DNA sequence analysis of the amplicons con- 
Table 5: Properties of the NgoФ3 CDS' sequences

\begin{tabular}{|c|c|c|c|c|}
\hline NgoФ3 CDSs & Genome position & Length (aa) & Putative function & $\begin{array}{l}\text { Significant matches to proteins in GeneBank (Scores represent filtered BLASTP \% } \\
\text { identities over stated number of amino acid) }\end{array}$ \\
\hline NGOI6I3 & $1592225-1593043$ & 384 & integrase & $\begin{array}{l}\text { [Xylella fastidiosa Dixon] (phage integrase family) } 052435,52 \% \text { on, } 367, \text { [Pseudomonas } \\
\text { syringe tomato str. DC3000] } 24,38 \% \text { on } 340 \text {, int [Azoarcus sp. EbNI] } 25,42 \% \text { on } 365\end{array}$ \\
\hline NGOI6I4 & $1595199-1595750$ & 88 & NS & \\
\hline NGOI 625 & $1596026-159624 \mid$ & 138 & NS & \\
\hline NGOI626 & $1583028-1584 \mid 82$ & 215 & conserved hypothetical protein & CDS2I [Bacteriophage bIL3II] (pfam GepA,) $29,48 \%$ on II6 \\
\hline NGOI627 & $1584232-1584498$ & 133 & hypothetical protein & HP2p I4 protein [Haemophilus phage (pfam UPFOI50 family) HP2] $34,54 \%$ on 129 \\
\hline NGOI 628 & $1590177-1590593$ & 60 & conserved hypothetical protein & [HPIpI8] protein [Haemophilus (COG I724) phage HPI] $60,74 \%$ on $5 \mathrm{I}$ \\
\hline NGOI 629 & $1590602-1591249$ & 272 & NS & \\
\hline NGOI 634 & $1591369-1591770$ & 183 & hypothetical protein & $\begin{array}{l}\text { hypothetical protein [P27p I7] [Bacteriophage P27] } 30,51 \% \text { on I } 47 \text { replication protein } \\
\text { [SfVp87] [Shigella flexneri bacteriophage V] } 32,54 \% \text { on } 87\end{array}$ \\
\hline NGOI635 & $1591873-1592055$ & 71 & NS & \\
\hline NGOI636 & $1596419-1597036$ & 205 & DnaC-like protein & $\begin{array}{l}\text { [STM2625] protein [Phage Gifsy-I] (pfam IstB family) } 37,51 \% \text { on } 201 \text {, replication } \\
\text { protein DnaC [Bacteriophage P27] } 37,56 \% \text { on } 192\end{array}$ \\
\hline NGOI637 & $1597|06-159726|$ & 51 & NS & \\
\hline NGOI639 & $1597884-1598387$ & 167 & hypothetical protein & NMBIII6 [Neisseria meningitidis MC58] 88,96\% on 27 \\
\hline NGOI65I & $1608278-1608616$ & 113 & $\begin{array}{l}\text { Neisseria-specific protein, } \\
\text { uncharacterized }\end{array}$ & \\
\hline NGOI652 & $16098 \mid 8-1608823$ & 332 & putative antirepressor & protein Ant [Bacteriophage (pfam Bro-N family) I085 Aaphi23] \\
\hline
\end{tabular}

firmed that the amplicons contained the predicted gene. When $N$. meningitidis or N. lactamica genomic DNA were tested, only non-specific PCR products were formed, suggesting the lack of these genes in these species (data not shown). When we tested for the formation of the PCR product corresponding to NGO0488 encoding the putative holin, products were formed with DNA isolated from strains FA1090, MS11 and WR220, but not with WR302 or 1291 DNA (Fig. 3C). Since the sequence corresponding to NGO0488 is identical with the sequence encoding NGO1106 present in NgoФ2, the lack of the proper PCR product indicates the lack of a complete NgoФ1 and NgoФ2 phage genome in these two strains, or that there is CDS encoding a different holin. Similarly, when we used the primers specific for the NGO1116 (present in NgoФ2), encoding putative repressor protein, the correct PCR product was formed with N. gonorrhoeae FA1090 and 1291 chromosomal DNAs but not with WR220 genomic DNA (data not shown). Using the PCR and primers specific for NgoФ3-NgoФ5, we found that the genes were variably present in the strains that we tested (Fig. 4).

\section{Biological activity of the prophage repressor genes}

The maintenance of the lysogenic state is most often maintained by the action of a repressor gene. Functionally, the repressor is silencing the activity of most of prophage genes. However, the expression of several genes, whose transcription is constitutive, is independent of its control. Recently it was shown that host genes can be regulated by phage repressors active in the lysogenic cells [23]. If this were true for the dsDNA prophages integrated into N. gonorrhoeae FA1090, we would expect that the phage repressors could influence the expression of cellular genes. We tested for their biological activity in E. coli.
The analysis of the NgoФ1 and NgoФ2 genomes allowed us to tentatively identify the repressor genes in both prophages as the CDSs NGO0479 and NGO1116 (Fig. 2, Table 4 and Table 5). Both genes carrying only the coding sequences were cloned in E. coli in pMPMK6 $\Omega$ [24], where expression of the gene was placed under control of the pBAD promoter. We expressed the repressor and tested it for its ability to influence the growth of E. coli and for its ability to inhibit the propagation of phage $\lambda$. The first experiment showed that even without induction, the presence in $E$. coli of a plasmid that encodes the repressors inhibits the growth of the host $E$. coli strain. The induction of NGO0479 by arabinose resulted in cell death (Fig. 5A) but not cell lysis (data not shown). Loss of viability seemed to be dependent on the level of protein expression, as maximal induction of the pBAD promoter $(0.1 \%$ arabinose) produced a rapid and almost immediate decrease in cell viability: lower amounts of induction produced reduced killing, or simple growth inhibition. A similar effect was also observed after induction of the expression of NGO1116 (Fig. 5B). From this data we concluded that cell death results from the expression of the cloned phage genes.

To test if cell death was the result of the influence of the expression of chromosomally encoded genes, the influence of the expression of the two repressors on propagation of the phage $\lambda$ was tested. Plasmids encoding both repressors were introduced into $E$. coli 3102, a strain that is lysogenic with $\lambda_{\mathrm{cts} 857}$. The induction of the NGO0479 by the presence of $0.001 \%$ arabinose, a concentration that induced the expression of some repressor and inhibited the growth of $E$. coli, did not result in significant death of the culture. Heat induction of the $\lambda$ phage did not induce cell lysis but blocked completely production of the progeny phage (Fig. 6). On the other hand, the induction of 
Table 6: Properties of the NgoФ4 CDS' sequences

\begin{tabular}{|c|c|c|c|c|}
\hline NgoФ4 CDSs & Genome position & Length (aa) & Putative function & $\begin{array}{l}\text { Significant matches to proteins in GeneBank (Scores represent filtered BLASTP \% } \\
\text { identities over stated number of amino acid) }\end{array}$ \\
\hline NGOI000 & $982212-984008$ & 75 & RecB family exonuclease & \\
\hline NGOI00I & $973188-973673$ & 161 & RecB family exonuclease & \\
\hline NGOI002 & $973680-974048$ & 122 & transcriptional factor & $\begin{array}{l}\text { [Exiguobacterium sp. } 255-15 \text { ] antiterminator } 27,53 \% \text { on } 77 \text { (traA) [Lactococcus lactis] } \\
20,46 \% \text { on } 100\end{array}$ \\
\hline NGOI003 & $977880-9783 \mid 4$ & 184 & hypothetical protein & BH0339 [Bacillus halodurans C-125] (pfam DUF694 family) $36,55 \%$ on 180 \\
\hline NGOI004 & $978515-978889$ & 119 & NS & \\
\hline NGOI005 & $978886-979764$ & 288 & NS & \\
\hline NGOI006 & $980160-980540$ & 116 & possible transposase & [NMAI60Ib][Neisseria meningitidis Z249I 79,83\% on 43 \\
\hline NGOI007 & $980749-981042$ & 69 & hypothetical protein & $\begin{array}{l}\text { VT2-Sap8I [Bacteriophage VT2-Sa] (pfam zf-dskA-traR family) } 42,55 \% \text { on69, phi4795p07 } \\
\text { [Phage phi4795]40,53\% on } 69\end{array}$ \\
\hline NGOI008 & $981023-981313$ & 96 & Neisseria-specific protein & NMBIO87 [Neisseria meningitidis MC58] 44,56\% on 67 \\
\hline NGOI009 & $974075-974617$ & 95 & Neisseria-specific protein & NMBI0I4 [Neisseria meningitidis MC58] $93,94 \%$ on 75 \\
\hline NGOIOIO & $975275-976|4|$ & 144 & conserved hypothetical protein & Pseudomonas aeruginosa $32,51 \%$ on 137 \\
\hline NGOI0II & $976|9|-97654 \mid$ & 124 & NS & \\
\hline NGOIOI2 & $976976-977185$ & 292 & NS & \\
\hline NGOIOI3 & $977473-977760$ & 126 & transcriptional regulator & $\begin{array}{l}\text { [NMBI007] [Neisseria meningitidis pfam HTH } 3 \text { family phage repressor MC58] 60,72\% } \\
\text { on } 126\end{array}$ \\
\hline NGOI0I4 & $972837-973064$ & 97 & hypothetical protein & $\begin{array}{l}\text { NMBIO05 [Neisseria meningitidis MC58] 79,84\% on } 73 \text { B3CDSI7 [Bacteriophage B3] } \\
46,59 \% \text { on } 47\end{array}$ \\
\hline NGOI0I5 & $974783-975142$ & 96 & Neisseria-specific protein & $\begin{array}{l}\text { NMBI } 003 \text { [Neisseria meningitidis MC58] } 77,90 \% \text { on } 95 \text { hypothetical protein B3CDSI } 4 \\
\text { [Bacteriophage B3] } 32,61 \% \text { on } 90\end{array}$ \\
\hline NGOI020 & $977 \mid 78-977468$ & 598 & putative transposase & $\begin{array}{l}\text { [Bacteriophage B3] } 43,61 \% \text { on } 585 \text { (pfam rve family) integrase protein [Salmonella } \\
\text { typhimurium LT2] } 25,41 \% \text { on } 383\end{array}$ \\
\hline
\end{tabular}

the NGO1116 and the heat induction of phage $\lambda$ resulted in some cells lysis (data not shown) and the 10 times lower phage production than without the presence of the NGO1116 gene product (Fig. 6). This data indicates that very low level of expression of both repressors influences the propagation of the $\lambda$ phage.

Since the expression of the phage repressors affected the growth of E. coli, we hypothesized that it was influencing the expression of as yet undefined genes. To further support this hypothesis, we tested the influence of the NGO1116 product on the expression of different HP1 phage promoters. We constructed plasmids carrying transcriptional fusions in which the xylE gene was expressed from the different HP1 phage promoters. The data in Table 8 indicate that both promoters are active in E. coli, as evidenced by the presence of XylE activity in supernatants obtained from host cells grown in the absence of arabinose. When arabinose was added, the XylE activity found in supernatants isolated from these strains indicates that $P_{\mathrm{LHP} 1}$ promoter but not $\mathrm{P}_{\mathrm{RHP} 1}$ activity is inhibited. This data indicates that the NGO1116 gene product can differentially repress promoter activity, and suggests that its expression in the gonococcus could silence prophage gene expression in the N. gonorrhoeae genome.

\section{The putative holin proteins}

Most bacteriophage must lyse their host cells to liberate the progeny virions. The decision of when to terminate the infection and to lyse the host is the only major decision made in the vegetative cycle [25]. Thus, if the prophage sequences present in the genome of $N$. gonorrhoeae are able to excise from the bacterial genome and produce progeny, they should encode a lytic system. Phages with double-stranded nucleic acid genomes use the "holin-endolysin" strategy [23]. In this scheme, the phage encodes murein-degrading enzyme, an endolysin, and a second membrane-embedded protein, holin, which serves to activate the endolysin at the defined time. Holins are small membrane proteins that accumulate in the cytoplasmic membrane of the host. The holins are represented by more than 250 members belonging to 50 gene families with no recognizable detectable sequence similarity [25]. The common property of all holins is the presence of one or more trans-membrane domains [25], which allows for their identification in the phage sequences. Our analysis of the proteins encoded by the prophage NgoФ1-NgoФ3 sequences suggested that the NGO0488, NGO1106 and NGO1622 could potentially encode a holin. NGO0488 and 1106 are identical and encode for a protein of 49 amino acids, while NGO1622 encodes for a protein of 91 amino acids. These proteins do not showhomology to any other proteins and each possesses one TM domain. To test whether the Ngo $\Phi 1$ putative holin can act as a true holin, we tested to see if this CDS could complement mutations in the phage $\lambda S$ gene. For controlled expression of NGO0488, this gene was inserted downstream of the pBAD promoter of pMPMK6 [24] resulting in the construct pMPMK6hol. The E. coli MM 294 cells $\left(\lambda c \mathrm{I}_{857}\right.$ Sam7), carrying the plasmid pMPMK6::hol were grown at $30^{\circ} \mathrm{C}$ to the optical density of $\mathrm{OD}_{600}$ of 0.6 . At that time, the heat shock was carried out $\left(45^{\circ} \mathrm{C}\right.$ for $\left.20 \mathrm{~min}\right)$ and arabinose was added to a final concentration of $1.0 \%$. In the presence of hol gene of NgoФ1 phage, even without its induction, the cells grew very slowly. We were unable to detect the lysis of these cells after induction by arabinose 
Table 7: Properties of the Ngo $\Phi 5$ CDS' sequences

\begin{tabular}{|c|c|c|c|c|}
\hline NgoФ5 CDSs & Genome position & Length (aa) & Putative function & $\begin{array}{l}\text { Significant matches to proteins in GeneBank (Scores represent filtered BLASTP \% } \\
\text { identities over stated number of amino acid) }\end{array}$ \\
\hline NGO0720 & $721256-721459$ & 67 & hypothetical protein & NMBI387 [Neisseria meningitidis MC58] 99,99\% on 44 \\
\hline NGO0721 & $729286-729570$ & 337 & hypothetical protein & NMAI 603 [Neisseria meningitidis Z249I] 72,76\% on 173 \\
\hline NGO0722 & $721459-722472$ & 46 & hypothetical protein & NMAI602 [Neisseria meningitidis Z249I] $94,97 \%$ on 36 \\
\hline NGO0723 & $722517-722657$ & 82 & hypothetical protein & $\begin{array}{l}\text { NMA } 1216 \text { [Neisseria meningitidis Z249I] } 94,100 \% \text { on } 37 \mathrm{HP} 2 \mathrm{p} 14 \text { [Haemophilus phage } \\
\text { HP2] 3I, } 61 \% \text { on } 2\end{array}$ \\
\hline NGO0724 & $72289-723144$ & 40 & hypothetical protein & NMA I 216 [Neisseria meningitidis Z249I] 97, 97\% on 34 \\
\hline NGO0725 & $723086-723208$ & 102 & hypothetical protein & NMBI I I 6 [Neisseria meningitidis MC58] $54,62 \%$ on 90 \\
\hline NGO0727 & $723158-723466$ & 182 & phage baseplate assembly & $\begin{array}{l}\text { [00965] [Escherichia coli CFT073] (pfam Baseplate J family) } 54,67 \% \text { on I46, gPJ } \\
\text { [Enterobacteria phage P2] } 48,61 \% \text { on I } 46\end{array}$ \\
\hline NGO0728 & $726767-727315$ & 300 & $\begin{array}{l}\text { phage baseplate assembly } \\
\text { protein }\end{array}$ & $\begin{array}{l}\text { CDSI7 [bacteriophage phi CTX] (pfam Phage base V family) gpW [Enterobacteria } \\
\text { phage P2] (pfam GPW gp } 25 \text { family } 37,57 \% \text { on } 90\end{array}$ \\
\hline NGO0729 & $727336-728238$ & 70 & putative cl-like repressor & [Streptococcus pyogenes phage 315.3 ] $45,67 \%$ on 31 \\
\hline NGO0730 & $728344-728556$ & 217 & ISI0I6C2 transposase & $\begin{array}{l}\text { [Neisseria meningitidis MC58] } 78,82 \% \text { on } 217 \text { protein V6-Haemophilus influenzae } 55,69 \% \\
\text { on } 175\end{array}$ \\
\hline NGO073। & $7286 \mid 1-729264$ & 94 & hypothetical protein & NMAI 219 [Neisseria meningitidis Z249I] 97, 97\% on 82 \\
\hline
\end{tabular}

(data not shown). Thus, in these experiments the uninduced level of holin was sufficient to inhibit the growth of E. coli cells, carrying an uninduced $\lambda$ prophage.

In order to assess whether Hol resembles $S$ and other holins-particularly with respect to the salutary triggering phenotype that characterizes holin functions, conditions which allow for even tighter regulation of the PBAD promoter but allow for a high level of induction were needed. The experiments were then carried out in a similar way, but the culture, prior to heat inactivation and arabinose induction, was grown in the presence of $1 \%$ glucose, to further block the pBAD promoter through catabolic repression. The growth in the presence of glucose was still slower than the growth of $E$. coli MM 294 cells $\left(\lambda c \mathrm{I}_{857}\right.$ Sam7) without the presence of hol gene. However the induction of hol gene resulted in abrupt lysis of entire culture, with the onset of lysis occurring about $20 \mathrm{~min}$ after induction (Fig. 7). Thus, like the well-studied $\lambda$ holin $S$, and other phage holins, the holin of Ngo $\Phi 1$ causes abrupt lysis of E. coli cells at a defined time.

\section{Presence of the dsDNA phages in N. gonorrhoeae supernatants}

To detect the presence of phage DNA in phage particles released from the cells during growth, the same method was used as described previously for the detection of the filamentous ssDNA phages in $N$. meningitidis cultures
[16]. In this method, the presumptive phage particles are precipitated with PEG and the precipitate intensively treated with DNase and RNAse to remove contaminating bacterial genomic DNA and RNA. The DNA is then isolated from the phage and used as a template in PCR reactions. The presence of the particular phage DNA sequence in such phage preparations means that the prophage genome must be excised from the bacterial genome, and after a replication cycle, packaged into the phage particles and released from the cells.

In similar experiments, the presence of the dsDNA isolated from the crude phage preparation obtained from the $N$. gonorrhoeae FA1090 cultures was tested. Using primers specific for NgoФ1 (NGO0495) we were able to show the formation of predicted PCR product (Fig. 8). To show that the phage preparation does not contain the bacterial genomic DNA released from the growing bacterial cells, we performed a PCR amplification for the chromosomally encoded gene, lpt3. The data (Fig. 8) indicate that an amplicon was formed when chromosomal DNA was used as template, but not when phage DNA was employed. This result indicates that in N. gonorrhoeae FA1090 the prophage sequences can be excised from the chromosome, replicate and form phage particles that are released from the bacterial cells. We also tested the possibility that such phage can form plaques on $N$. subflava, N. lactamica

Table 8: The influence of expression of CDSI I 16 on the different promoter activity.

\begin{tabular}{|c|c|}
\hline Strain & XyIE activity $(U)^{a}$ \\
\hline E. coli TopI0 (pMPMT4::CDSIII6, pMPMK6:: $\mathrm{P}_{\mathrm{RHPI}}$ ) - ara & $22.3+/-10.2$ \\
\hline E. coli TopI0 (pMPMT4::CDSIII6, pMPMK6:: $\left.\mathrm{P}_{\mathrm{RHPI}}\right)+$ ara & $20+/-9.5$ \\
\hline E. coli TopI0 (pMPMT4::CDSIII6, pMPMK6::P LHPI $_{1}$ ) - ara & $268.2+/-33.1$ \\
\hline E. coli Top 10 (pMPMT4::CDSI I 16, pMPMK6:: $\left.P_{\text {LHPI }}\right)+$ ara & $20.0+/-9.2$ \\
\hline
\end{tabular}

aOne unit of XylE activity corresponds to the formation of I nmol of 2-hydroxymuconic semialdehyde per min at $22^{\circ} \mathrm{C}$. 


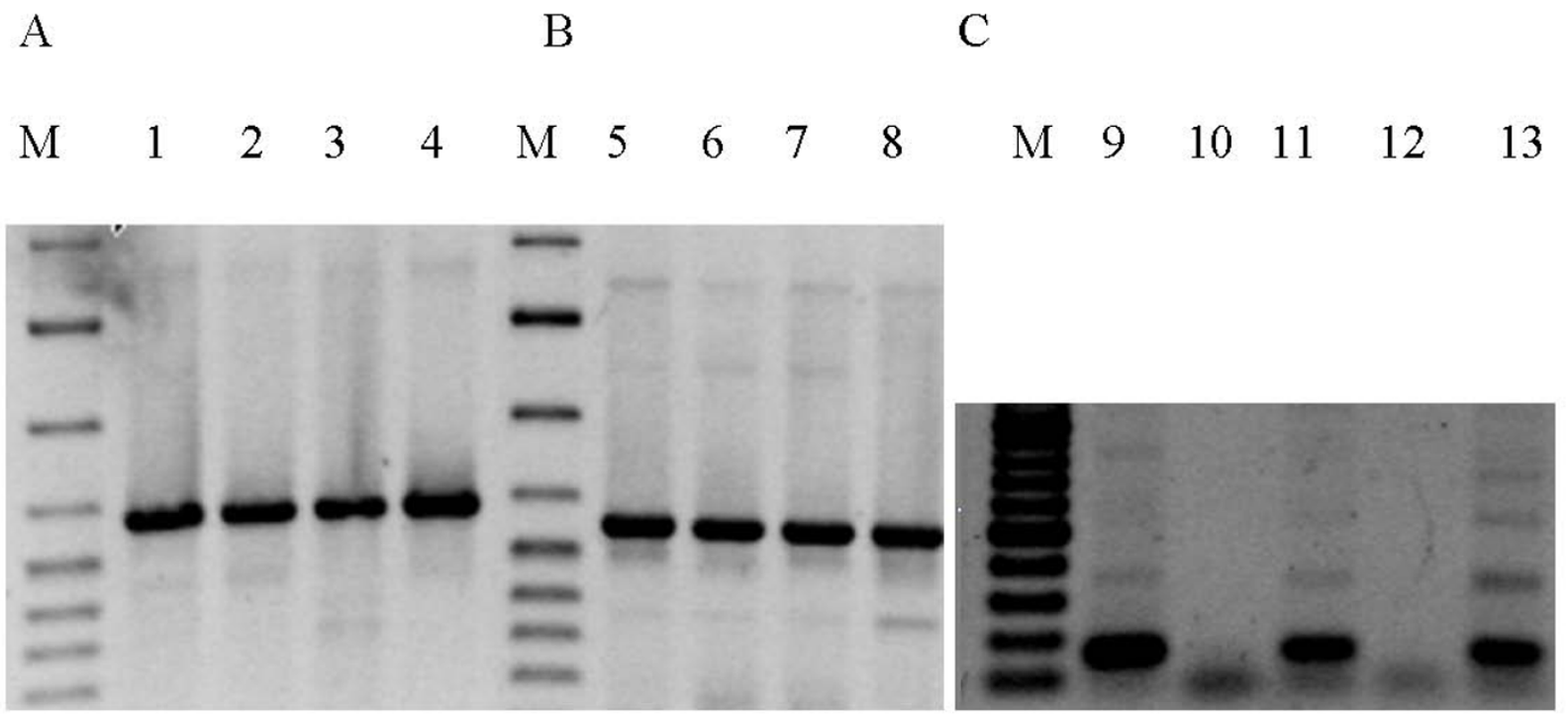

Figure 3

PCR detection of the presence of dsDNA prophage sequences $\mathbf{N g o} \Phi$ I and $\mathbf{N g o} Ф 2$ sequences in different

strains of Neisseria. A. Detection of the prophage NgoФI CDS495 sequence encoding putative large terminase subunit, B. Detection of the prophage NgoФ2 CDS1098 sequence encoding putative large terminase subunit, C. Detection of the CDS448 encoding putative holin of NgoФI/NgoФ2. Lanes I, 5, 9, N. gonorrhoeae FA I090, lanes 2, 6, I ; N. gonorrhoeae MSI I, Lanes 3, 7, I3; N. gonorrhoeae WR220, lanes 4, 8, I2; N. gonorrhoeae WR302, Lane 10 N. gonorrhoeae I29I. M, molecular weight markers.

A $B$

$\begin{array}{llllllllllllllll}1 & 2 & 3 & 4 & \mathrm{M} & \mathrm{M} & 5 & 6 & 7 & 8 & 9 & \mathrm{M} & 10 & 11 & 12 & 13\end{array}$

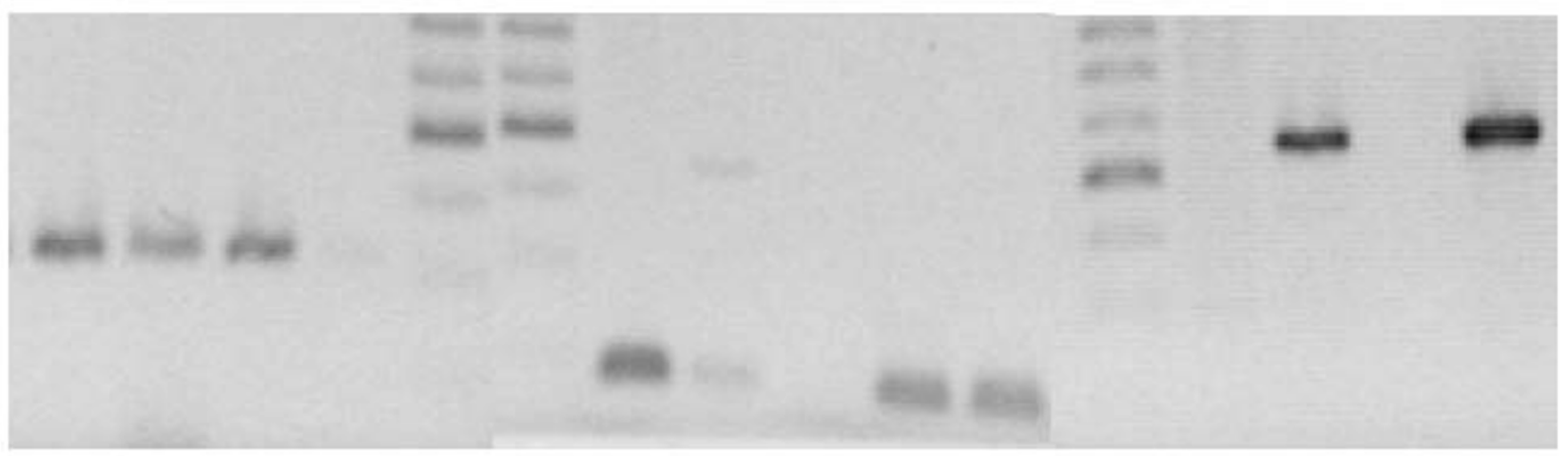

\section{Figure 4}

PCR detection of the presence of dsDNA prophage NgoФ3 - NgoФ5 sequences in different strains of Neisseria. A. Detection of the prophage Ngo $44 C D S I 013$ encoding the putative repressor protein, B. Detection of the prophage Ngo $\Phi 5$ CDS729 encoding the putative repressor, C. Detection of the CDSI 636 encoding putative dnaC gene of Ngo $\$ 3$. Lanes I, 5, I3; N. gonorrhoeae FA1090, lanes 2, 6; N. gonorrhoeae WR302, Lanes 3, 8; I I, N. gonorrhoeae MSI I, Lanes 4,7, I0; N. gonorrhoeae WR220, Lanes 9, 12, Neisseria gonorrhoeae I29I. M, molecular weight markers 

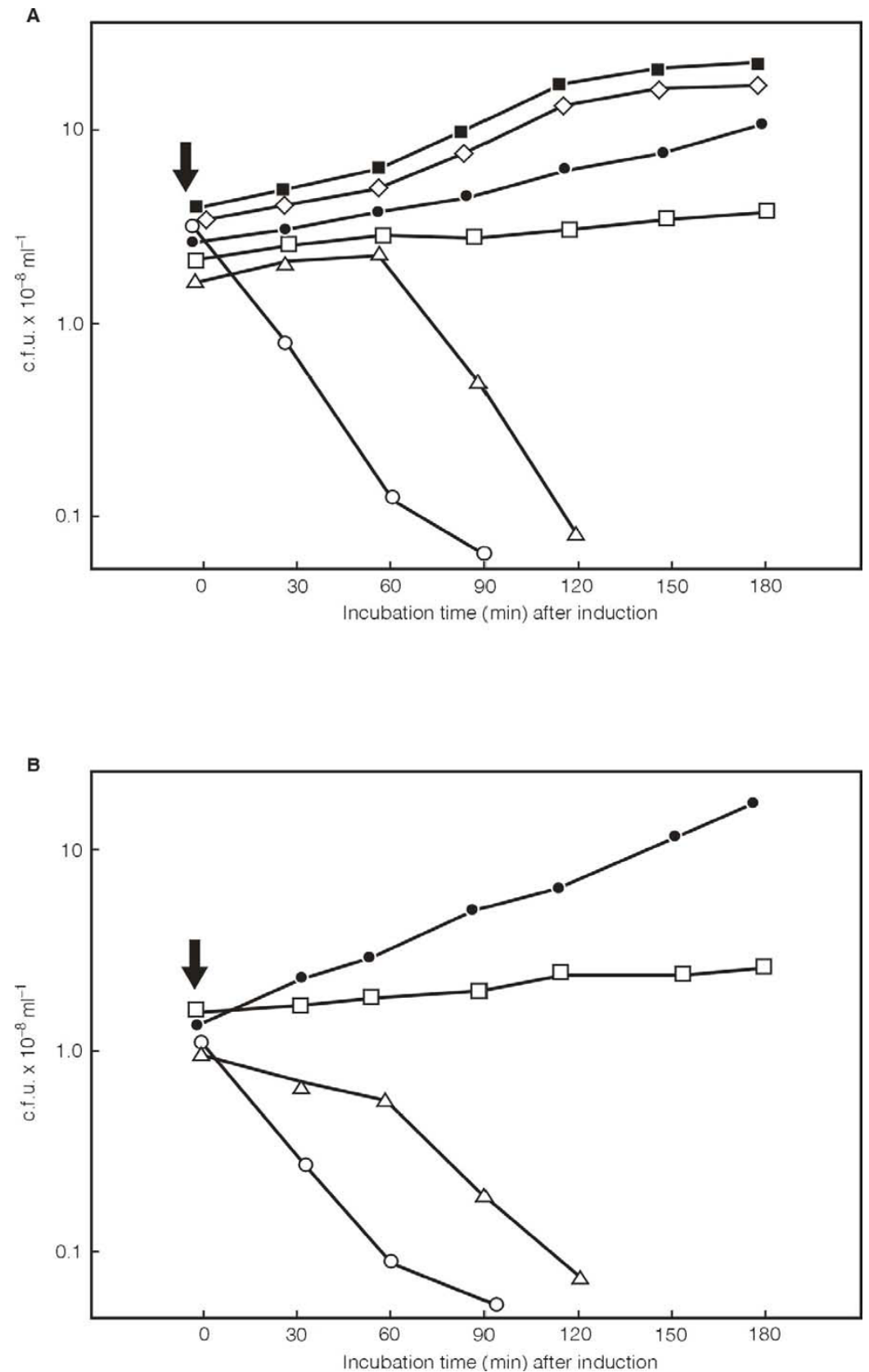

Figure 5

Influence of expression of the Ngo $\Phi$ I and $\mathrm{Ngo} \Phi 2$ putative promoters on the growth of $E$. coli Top I 0 cells as measured by the change of $(\mathrm{CFU} / \mathrm{ml})$. The overnight culture of the $E$. coli Top 10 cells carrying cloned CDS479 gene (A) or CDSI I I 6 (B) on the plasmid PMPMK6 grown in LB was diluted I:50 into $50 \mathrm{ml}$ of the fresh medium and grown at $37^{\circ} \mathrm{C}$ until the $\mathrm{OD}_{650}$ was equal of about 0.8 . At that time the culture was divided and the expression of the cloned gene was started by the addition of the different concentration of arabinose. (A) Symbols: (filled circles), E. coli Top 10 (pMPMK6::cds479) not induced; (open squares), E. coli Top 0 (pMPMK6::cds479) induced with $0.001 \%$ arabinose; (open triangles), E. coli Top 10 (pMPMK6::cds479) induced with 0.01\% arabinose; (open circles), E. coli Top 10 (pMPMK6::cds479) cells induced with 0.1\% arabinose; (filled squares), E. coli Top 10 (pMPMK6) cells not induced; (open diamonds), E. coli Top I0 (pMPMK6) cells induced with $0.1 \%$ arabinose. (B) Symbols: (filled circles), E. coli Top 10 (pMPMK6::cds III6) not induced; (open squares), E. coli Top I0 (pMPMK6::cds I I I6) induced with $0.001 \%$ arabinose; (open triangles) E. coli Top I0 (pMPMK6::cds I I I6) induced with 0.01\% arabinose; (open circles) E. coli Top 10 (pMPMK6::cds II 16) cells induced with $0.1 \%$ arabinose. The arrow shows the time when arabinose was added. 

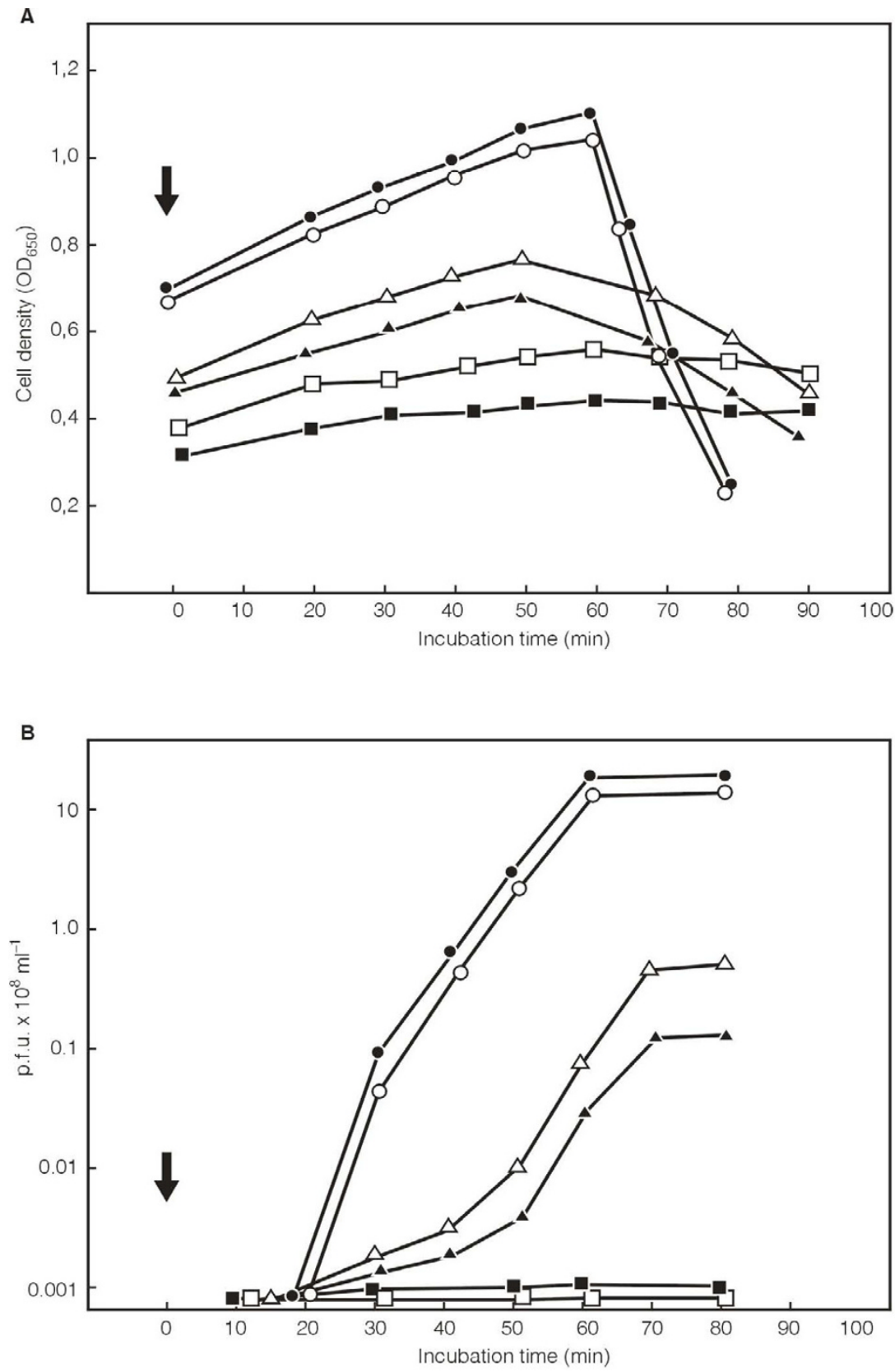

\section{Figure 6}

Influence of expression of the Ngo $\Phi$ I prophage CDS495 and Ngo 22 CDSI I I 6 encoding the putative repressors on production of the phage $\lambda$. E. coli $3102\left(\lambda_{\text {cl857 }}\right)$. Cells carrying cloned CDS479 or CDSIII 6 were grown overnight at $30^{\circ} \mathrm{C}$ and then diluted I:50 in the fresh LB medium. The growth was continued for $3 \mathrm{hr}$ at $30^{\circ} \mathrm{C}$. At that time the culture was divided and the expression of the cloned gene was induced by the addition of the arabinose to a final concentration of $0.001 \%$. After $45 \mathrm{~min}$ of growth at $30^{\circ} \mathrm{C}$ the cultures were heat induced at $43^{\circ} \mathrm{C}$ for 15 min and then the growth was continued at $37^{\circ} \mathrm{C}$. The samples were withdrawn at different times and the optical density $(A)$ and $(B)$ the free phage titer (after treatment with chloroform, $10 \%$ final concentration for $15 \mathrm{~min}$ ) were determined. Symbols: (filled circles) $E$. coli 3102 ( $\left.\lambda_{\text {cl857 }}\right)$ (pMPMK6) cells no arabinose was added; (open circles) E. coli 3102 ( $\left.\lambda_{\text {c1857 }}\right)$ (pMPMK6) cells induced with arabinose; (open triangles), $E$. coli 3102 ( $\left.\lambda_{\text {cl857 }}\right)$ (pMPMK6::cds I I 16) no arabinose added; (filled triangles) $E$. coli 3102 ( $\lambda_{\text {cl857 }}$ ) (pMPMK6::cds I I 16) cells induced with arabinose; (open squares), E. coli 3102 ( $\left.\lambda_{\mathrm{cl} 1857}\right)$ (pMPMK6::cds479) no arabinose added; and (filled squares), $E$. coli $3102\left(\lambda_{c 1857}\right)$ (pMPMK6::cds479) cells induced with arabinose. The arrow shows the time when the heat induced cultures were transferred into $37^{\circ} \mathrm{C}$. 


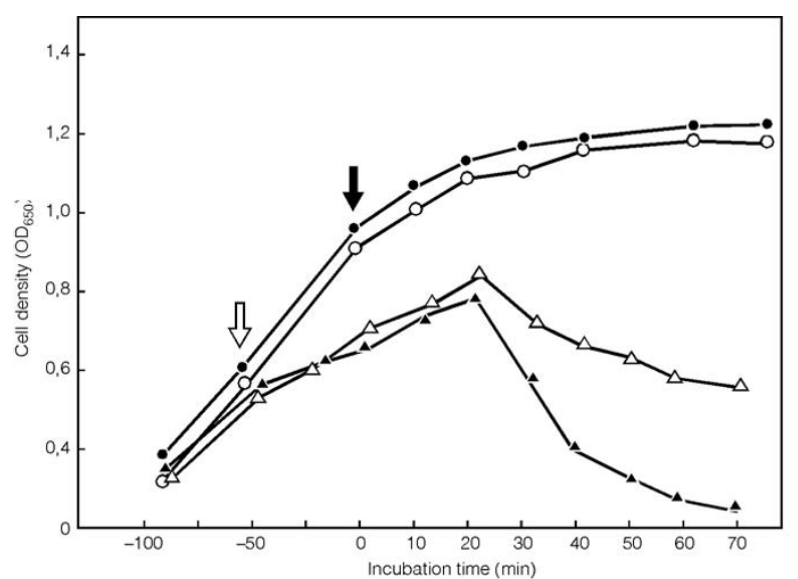

Figure 7 Complementation of the $\lambda \mathrm{S}$ am 7 mutant with the CDS488 of NgoФI. $50 \mathrm{ml}$ of LB medium containing the I\% glucose was inoculated with I $\mathrm{ml}$ of overnight culture of $E$. coli MM294 $\lambda$ I I I (cl857 Sam7) carrying PMPMK6::cds448) grown in the LB medium in the presence of $I \%$ glucose at $30^{\circ} \mathrm{C}$. After $2.5 \mathrm{~h}$ of growth at $30^{\circ} \mathrm{C}$ the culture was centrifuged at $5000 \mathrm{rpm}$ for $10 \mathrm{~min}$, and the cells suspended in the $50 \mathrm{ml}$ of fresh LB medium without glucose. The $\lambda$ I I I (cl857 Sam7) was induced by incubation of the culture at $44^{\circ} \mathrm{C}$ for I 5 min and the expression of the CDS488 gene was (or not) induced by the addition of arabinose to a final concentration of $0.001 \%$. The white arrow shows the time of CDS488 induction, the black arrow shows the time of heat induction. Symbols: (filled circles), E. coli MM294 $\lambda$ I I I (cl857 Sam7) carrying PMPMK6), no arabinose induction; (open circles), $E$. coli MM294 $\lambda$ I I I (cl857 Sam7) carrying PMPMK6, with arabinose induction; (open triangles), E. coli MM294 $\lambda$ III (cl857 Sam7) carrying PMPMK6::cds488, no induction with arabinose; and (filled triangles), E. coli MM294 $\lambda$ I I I (cl857 Sam7) carrying pMPMK6::cds488, induction with arabinose.

or $N$. cinerea cells, but without success (data not presented).

After identifying conditions where we could isolate supernatants containing phage DNA, we analyzed the culture supernatants for bacteriophage particles by electron microscopy. Phage particles (both filamentous and lambda-like) were readily visualized by electron microscopy. The data presented in figure 9 is an example of one of the lambda-like phage particles. This phage clearly contains a head and tail structure. Culture supernatants also contained numerous tail-less heads, and filamentous particles of varying lengths (data not shown). Given the diversity of phage encoding sequences in the genome of the producing strain, we did not attempt to determine which phage DNAs sequence was responsible for the production of the phage shown.

\section{Discussion}

The existence of prophage DNA sequences in the bacterial chromosomes is very common [3]. It is also very common that several different prophage sequences can be present in the genome of a particular bacterial strain. For example, in eleven Salmonella enterica serovars Typhi and Typhimurium, two Yersinia pestis strains, Shigella flexnerii, two Xylella fastidiosa, and four E. coli strains that have been sequenced, each carries between 7 to 20 prophages (see review by Casjens [3]). Cryptic prophage DNA sequences have been found in several $N$. meningitidis strains as well $[15,16]$. Our analysis of nine DNA sequences of $N$. gonorrhoeae allowed us to identify the presence of two different types of bacteriophage DNA sequences in this species. The first group is represented by sequences that are homologous to the filamentous ssDNA prophages recently discovered in the chromosome of $N$. meningitidis $[16,18]$. The second group is represented by the sequences that show the high homology to the tailed dsDNA phages present in diverse groups of bacteria. The overall genetic organization of these phages resembles mostly that of $\mathrm{P} 2$ genome ld MACROBUTTON endnote+.cit [3]. This is in sharp contrast to N. meningitidis where dsDNA prophage sequences show homology to Mu-like phages representing a very specific group of phages [15].

NgoФ1 and NgoФ2 could encode functional bacteriophages since they seem to encode all of genes necessary for lytic growth. The ability to produce functional bacteriophage is further supported by the fact that we were able to detect the presence of some of these genes outside of the cells in a DNase resistant form (phage particles). We were able to visualize phage particles. We showed that some of the genes are biologically active. Since we were unable to further propagate phages on any of the strains tested, it suggests that each strain is expressing the appropriate lysogenic control genes.

It is much less probable that the phage belong to gene transfer agents that are tailed phage-like particles that encapsidate random fragments of the bacterial genome [3] since we were unable to detect the chromosomal sequences in the DNase resistant forms. Three of the dsDNA prophages present in N. gonorrhoeae FA1090 are probably defective forms of Ngo $\Phi 1$ and Ngo $\Phi 2$, being in the stage of complex decay of prophages. We believe that Ngo $\Phi 5$ can be classified as a bacteriocin since it seems to encode mainly the genes of phage tail.

The presence of two types of biologically active prophage in the $N$. gonorrhoeae may form the molecular explanation for the observation of the formation of autoplaquing [12]. While Campbell and coworkers were clearly able to induce gonococci to produce products capable of inhibiting their growth, they were unable to demonstrate the 
A

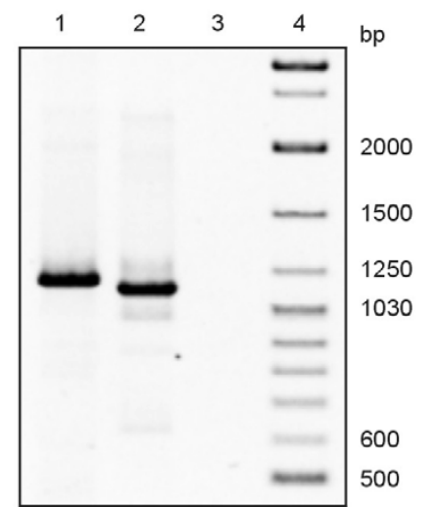

Figure 8

Detection of the extracellular dsDNA of Ngo $\Phi I$ and Ngo $\Phi 2$ phages of $\mathbf{N}$. gonorrhoeae. PCR amplification was performed on DNA from phage preparation to detect the presence of the DNA sequence corresponding to large terminase encoded by CDS488 (Lane AI) or CDSI I I 6 (Lane A2). In the control experiment the PCR product corresponding to the chromosomal DNA sequence of $N$. gonorrhoeae FAI090 encoding the Ipt3 gene was not detected (Lane A3) in the phage preparation while the same PCR product was formed using the chromosomal DNA as a substrate (Lane BI).

propagation of phage. On the other hand, it is possible that autoplaquing does not result from phage propagation, but rather an alteration in an autoylytic mechanism within the cell, as suggested for autoplaquing in Myxococcus [26]. It could also be the result of down-regulation of the phage repressors and up-regulation of the phage encoded holin-endolysin lytic system that seem to be encoded by Ngo $\Phi 1$ and Ngo $\Phi 2$ prophages, in response to an environmental change.

To test for the presence of prophage sequences in different gonococcal strains we determined the presence of three different genes present in Ngo $\Phi 1$ and NgoФ2 using a PCR method, with the specificity of the PCR product verified by DNA sequence analysis. The results indicate that the prophage sequences detected in strain FA1090 are not present in all N. gonorrhoeae strains. Although, the specific PCR products encoding the large terminase subunits of NgoФ1 and NgoФ2 were formed using the chromosomal DNA from FA1090, MS11,1291 and WR302, the DNA encoding the holin gene (NGO0488) was not detected in 1291 and WR302. Similarly, we were unable to detect the presence of the DNA sequences representing phages NgoФ3-NgoФФ5 in strains as WR220 or 1291. However, the lack of corresponding PCR products or very low amount of product formation, as in case of strain WR220 and 1291 the DNA encoding holin gene could be due to the differences in the DNA sequence encoding the genes

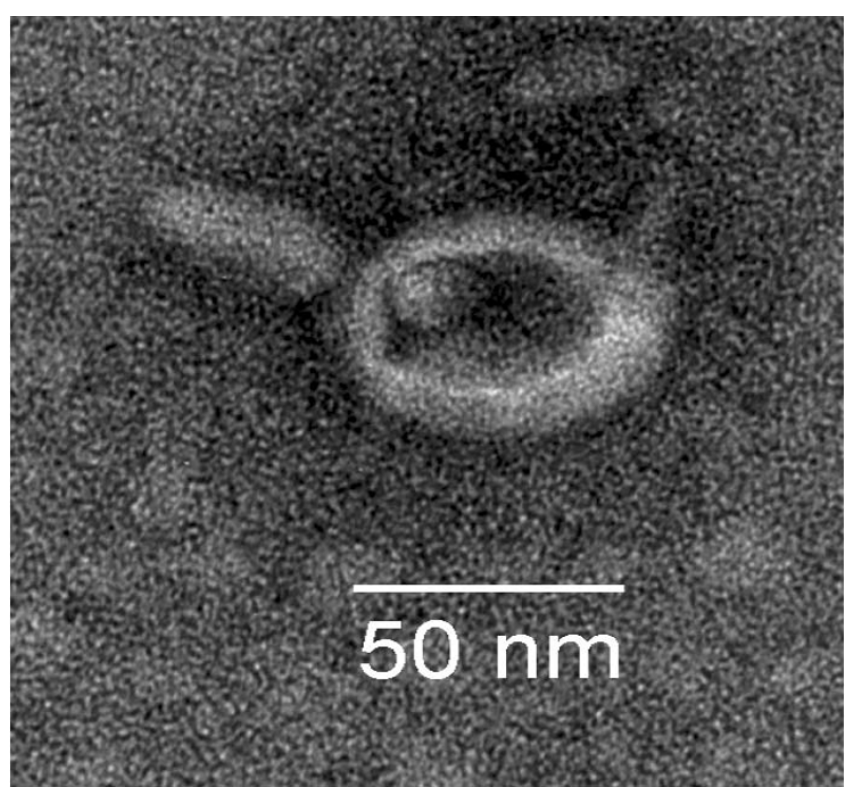

Figure 9

Transmission electron micrograph of gonococcal bacteriophage. Culture supernatants were precipitated with PEG 8000, dialyzed against TE buffer, added to a goldgrid, stained with Uranyl acetate and visualized on a Zeiss EMI0CA electron microscope (I60,000 magnification).

in particular strains, thus changing the formation of the hybrids between primers and template DNA used for PCR reaction and the chromosomal DNA.

Presence of the prophage sequences in the bacterial genomes may have a profound effect on the pathogenicity of the host cell (see review by Wagner \& Waldor, [27]) as well as on the population fitness [23]. Over time, a number of toxin genes have been found to be phageencoded and it has become clear that toxin genes are only a part of diverse group of virulence factors encoded by bacteriophages [27]. We do not know whether any of the identified prophage genes of $N$. gonorrhoeae can be recognized as encoding bacterial toxins. On the other hand the properties of the $\mathrm{NgO} \Phi 1$ and NgoФ2 genes encoding putative repressors could have a profound effect on the fitness of $N$. gonorrhoeae strains. In $E$. coli the expression of the $\lambda$ repressor inhibits the growth of cells in energy-poor environments, probably as an adaptive response to a host predation system [23]. We have shown that when E. coli is grown on a rich LB medium, the bacteria that express the repressor grows poorly and that induction of these genes inhibits of growth of cells, with high level of induction leading to cell death. This effect can be manifested by acting through the influence on the expression of different genes. The repressor of NgoФ1 seems to inhibit the expression of the $\lambda$ phage since even very low level of expression blocks the development of $\lambda$ particles. These 
Table I: List of primers used in this study

\begin{tabular}{|c|c|c|c|}
\hline Primer & Sequence (5'-3') & Description & PCR conditions \\
\hline FITerD F & $\begin{array}{l}\text { AATCACCATGCGCCAATCT } \\
\text { GCAACGCGCTCGA }\end{array}$ & $\begin{array}{l}\text { Amplifies the } 5^{\prime} \text { end of NGO0495 (putative terminase) } \\
\text { without any restriction sites }\end{array}$ & $\begin{array}{l}94^{\circ} \mathrm{C}, 5 \min . ; 2 \times\left(94^{\circ} \mathrm{C}, 48^{\circ} 45 \mathrm{sec}, 72^{\circ} \mathrm{C} \text { I min }\right) ; 30 \times \\
\left(94^{\circ} \mathrm{C}, 45 \text { sec.; } 63^{\circ} \mathrm{C}, 45 \mathrm{sec} \text {.; } 72^{\circ} \mathrm{C}, 3 \mathrm{~min} \text {.); } 72^{\circ} \mathrm{C}, 10\right. \\
\text { min. }\end{array}$ \\
\hline FITerD R & $\begin{array}{l}\text { TCCGTGTCCCATGTGCCG } \\
\text { TCATCCAACACCAT }\end{array}$ & $\begin{array}{l}\text { Amplifies the } 3 \text { ' end of NGO0495 (putative terminase) } \\
\text { without any restriction sites }\end{array}$ & \\
\hline F2Reg8L2 & $\begin{array}{l}\text { GCGAATTCGATGTCTGAA } \\
\text { TTTAAAGACCGCCTGAAAG AG }\end{array}$ & $\begin{array}{l}\text { Amplifies the } 5 \text { ' end of NGOI I I6 (putative repressor cl) } \\
\text { with EcoRI site }\end{array}$ & $\begin{array}{l}94^{\circ} \mathrm{C}, 5 \min . ; 2 \times\left(94^{\circ} \mathrm{C}, 30 \text { sec.; } 48^{\circ} \mathrm{C}, 45 \text { sec.; } 72^{\circ} \mathrm{C}, 2\right. \\
\text { min.); } 28 \times\left(94^{\circ} \mathrm{C}, 15 \text { sec.; } 50^{\circ} \mathrm{C}, 45 \text { sec.; } 72^{\circ} \mathrm{C}, 2 \text { min. }\right) \text {; } \\
72^{\circ} \mathrm{C}, 10 \text { min. }\end{array}$ \\
\hline F2Reg8Rt & $\begin{array}{l}\text { ATTCTGCAGTCACATCAAT } \\
\text { CCAACACGCTCCACCAAA AG }\end{array}$ & $\begin{array}{l}\text { Amplifies the } 3^{\prime} \text { end of NGOI I I6 (putative repressor cl) } \\
\text { with Pstl site }\end{array}$ & \\
\hline F2TerD F & $\begin{array}{l}\text { AATATTCGTCGTGCAGCG } \\
\text { GCCCCATTGCCACG }\end{array}$ & $\begin{array}{l}\text { Amplifies the } 5 \text { ' end of NGOI098 (putative terminase) } \\
\text { without any restriction sites }\end{array}$ & $\begin{array}{l}94^{\circ} \mathrm{C}, 5 \mathrm{~min} ; 30 \times\left(94^{\circ} \mathrm{C}, 45 \mathrm{sec} . ; 63^{\circ} \mathrm{C}, 45 \mathrm{sec} \text {. }\right) ; 72^{\circ} \mathrm{C} \text {, } \\
3 \mathrm{~min} . ; 72^{\circ} \mathrm{C}, 10 \mathrm{~min} .\end{array}$ \\
\hline F2TerD R & $\begin{array}{l}\text { CGGGCTGTTCAAGCCTTG } \\
\text { CCGGTACAAGGTTA }\end{array}$ & $\begin{array}{l}\text { Amplifies the } 3^{\prime} \text { end of NGOI098 (putative terminase) } \\
\text { without any restriction sites }\end{array}$ & \\
\hline F2antrep F & $\begin{array}{l}\text { GCCGGAATTCTCCAAGTT } \\
\text { TTAAACTTTCAAC }\end{array}$ & $\begin{array}{l}\text { Amplifies the } 5 \text { ' end of NGOI085 (putative } \\
\text { antirepressor) with EcoRI site }\end{array}$ & $\begin{array}{l}94^{\circ} \mathrm{C}, 5 \min . ; 3 \times\left(94^{\circ} \mathrm{C}, 1 \min . ; 44^{\circ} \mathrm{C}, 45 \mathrm{sec} . ; 72^{\circ} \mathrm{C}, 3\right. \\
\min .) ; 27 \times\left(94^{\circ} \mathrm{C} \text {, } 1 \text { min.; } 59^{\circ} \mathrm{C}, 45 \text { sec.; } 72^{\circ} \mathrm{C}, 3 \text { min. }\right) \text {; } \\
72^{\circ} \mathrm{C}, 10 \text { min }\end{array}$ \\
\hline F2antrep R & $\begin{array}{l}\text { TTATCTGCAGTTACCTTAC } \\
\text { CGTAGCCTTGCC }\end{array}$ & $\begin{array}{l}\text { Amplifies the } 3^{\prime} \text { end of NGOI085 (putative } \\
\text { antirepressor) with Pstl site }\end{array}$ & \\
\hline F3dnaC F & ACGCGCTGGAAAAACGCA TC & $\begin{array}{l}\text { Amplifies the } 5^{\prime} \text { end of NGOI } 636 \text { (putative replication } \\
\text { protein DnaC) without any restriction sites }\end{array}$ & $\begin{array}{l}94^{\circ} \mathrm{C}, 2 \min ; 3 \times\left(94^{\circ} \mathrm{C}, 1 \mathrm{~min} . ; 48^{\circ} \mathrm{C}, 45 \mathrm{sec} . ; 72^{\circ} \mathrm{C}, 3\right. \\
\min .28 \times\left(94^{\circ} \mathrm{C}, 45 \text { sec.; } 52^{\circ} \mathrm{C}, 45 \text { sec.; } 72^{\circ} \mathrm{C}, 2 \text { min. }\right) ; \\
72^{\circ} \mathrm{C}, 10 \text { min. }\end{array}$ \\
\hline F3dnaC R & TCCCAGTCGAACGGAATC AG & $\begin{array}{l}\text { Amplifies the } 3^{\prime} \text { end of NGO } 1636 \text { (putative replication } \\
\text { protein DnaC) without any restriction sites }\end{array}$ & \\
\hline Fag4cl F & TCACTTTACCAAGCGCAGT TT & $\begin{array}{l}\text { Amplifies the } 5 \text { ' end of } \mathrm{NGOIOI3} \mathrm{(putative} \mathrm{repressor} \mathrm{cl} \text { ) } \\
\text { without any restriction sites }\end{array}$ & $\begin{array}{l}94^{\circ} \mathrm{C}, 2 \min ; 3 \times\left(94^{\circ} \mathrm{C}, 1 \mathrm{~min} . ; 48^{\circ} \mathrm{C}, 45 \mathrm{sec} . ; 72^{\circ} \mathrm{C}, 3\right. \\
\min ), 28 \times\left(94^{\circ} \mathrm{C}, 45 \mathrm{sec} . ; 50^{\circ} \mathrm{C}, 45 \mathrm{sec} . ; 72^{\circ} \mathrm{C}, 2 \mathrm{~min} \text {. }\right) \\
72^{\circ} \mathrm{C}, 10 \mathrm{~min} .\end{array}$ \\
\hline Fag4cl R & AATTAGGCTTGAACCAAGC AG & $\begin{array}{l}\text { Amplifies the } 3 \text { ' end of } \mathrm{NGO} 1013 \text { (putative repressor cl) } \\
\text { without any restriction sites }\end{array}$ & \\
\hline Fag5cl F & TCTATCCAATCGAGGAACT GCC & $\begin{array}{l}\text { Amplifies the } 5 \text { ' end of } \mathrm{NGO} 0729 \text { (putative repressor cl) } \\
\text { without any restriction sites }\end{array}$ & $\begin{array}{l}94^{\circ} \mathrm{C}, 2 \mathrm{~min} ; 28 \times\left(94^{\circ} \mathrm{C}, 45 \mathrm{sec} . ; 52^{\circ} \mathrm{C}, 45 \mathrm{sec} \text {; } 72^{\circ} \mathrm{C} \text {, }\right. \\
2 \mathrm{~min} .) ; 72^{\circ} \mathrm{C}, 10 \mathrm{~min} .\end{array}$ \\
\hline Fag5cl R & CTACACGCCTTACAACCTT TCG & $\begin{array}{l}\text { Amplifies the } 3^{\prime} \text { end of } \mathrm{NGO} 0729 \text { (putative repressor cl) } \\
\text { without any restriction sites }\end{array}$ & \\
\hline RNFGFIc & $\begin{array}{l}\text { TATCTGCAGTCTAGAACTG } \\
\text { GCTCAAACGCCAT }\end{array}$ & Amplifies the 5 ' end of NGO0477 (putative repressor $\mathrm{cl}$ ) & $\begin{array}{l}94^{\circ} \mathrm{C}, 2 \mathrm{~min} ; 28 \times\left(94^{\circ} \mathrm{C}, 45 \mathrm{sec} . ; 52^{\circ} \mathrm{C}, 45 \mathrm{sec} \text {; } 72^{\circ} \mathrm{C} \text {, }\right. \\
2 \mathrm{~min} .) ; 72^{\circ} \mathrm{C}, 10 \mathrm{~min} .\end{array}$ \\
\hline FNGFICI & $\begin{array}{l}\text { GCGAATTCGATGCCTTTTA } \\
\text { TTATCGATTACCAATGC }\end{array}$ & Amplifies the $3^{\prime}$ end of NGO0477 & \\
\hline HPPRL_F & $\begin{array}{l}\text { CGCGGAATTCGACCCAGT } \\
\text { CAAATATATTCC }\end{array}$ & Amplifies the 5 ' region of $\mathrm{P}_{\mathrm{L}}$ promoter of phage $\mathrm{HPI}$ & $\begin{array}{l}94^{\circ} \mathrm{C}, 5 \mathrm{~min} ; 27 \times\left(94^{\circ} \mathrm{C}, 45 \mathrm{sec} . ; 56^{\circ} \mathrm{C}, 45 \mathrm{sec} . ; 72^{\circ} \mathrm{C}, \mathrm{I}\right. \\
\text { min.); } 72^{\circ} \mathrm{C}, 10 \mathrm{~min} .\end{array}$ \\
\hline HPPRL_R & $\begin{array}{l}\text { CGGGATCCTCGCAAAAAT } \\
\text { CGCCGAAAG }\end{array}$ & Amplifies the $3^{\prime}$ region of $P_{L}$ promoter of phage $\mathrm{HPI}$ & \\
\hline HPPR_F & $\begin{array}{l}\text { CGGGATCCCAGGTAACAC } \\
\text { AGTGATATAAC }\end{array}$ & Amplifies the 5 ' region of $P_{R}$ promoter of $\Phi$ HPI & $\begin{array}{l}94^{\circ} \mathrm{C}, 5 \mathrm{~min} ; 27 \times\left(94^{\circ} \mathrm{C}, 45 \mathrm{sec} . ; 56^{\circ} \mathrm{C}, 45 \mathrm{sec} . ; 72^{\circ} \mathrm{C} \text {, }\right. \\
\mathrm{I} \text { min.); } 72^{\circ} \mathrm{C}, 10 \mathrm{~min} .\end{array}$ \\
\hline HPPR_R & $\begin{array}{l}\text { CGCGGAATTCCCCGTATT } \\
\text { GGTAAATAATGG }\end{array}$ & Amplifies the $3^{\prime}$ region of $P_{R}$ promoter of $\Phi \mathrm{HPI}$ & \\
\hline HO488T4 F & $\begin{array}{l}\text { GCGAATTCGATGGATACC } \\
\text { CTGTTAAGCATCATCA }\end{array}$ & Amplifies the $5^{\prime}$ region of putative holin of $\mathrm{Ngo} \Phi \mathrm{I}$ & $\begin{array}{l}94^{\circ} \mathrm{C}, 2 \mathrm{~min} ; 2 \times\left(94^{\circ} \mathrm{C}, 48^{\circ} 45 \mathrm{sek}, 72^{\circ} \mathrm{C} \text { I min }\right) ; 28 \times \\
\left(94^{\circ} \mathrm{C}, 45 \mathrm{sec} \text {.; } 56^{\circ} \mathrm{C}, 45 \mathrm{sec} . ; 72^{\circ} \mathrm{C}, \mathrm{I} \text { min. }\right) ; 72^{\circ} \mathrm{C}, 10 \\
\text { min. }\end{array}$ \\
\hline HO488T4 B & $\begin{array}{l}\text { ATTCTGCAGCTTAATATCC } \\
\text { GAAGCCGTCGAAGT }\end{array}$ & Amplifies the $3^{\prime}$ region of putative holin of $\mathrm{Ngo} \Phi \mathrm{I}$ & \\
\hline
\end{tabular}

results suggest the tight control of genes encoding these repressors that would allow only very low levels of these proteins. The need for tight control of prophage gene expression is also evident from the activity of the NGO0488 encoding the holin. The activity of the gene has to be tightly controlled otherwise it is lethal for the cells and will results in the cell death.

Among different types of bacterial toxins that are phage encoded are the R- and F-type pyocins produced by $P$. aeruginosa. Pyocins are derived from a common ancestral origin with P2 phage and the $\lambda$ phage respectively [22]. The gene organization of the R2 and F2 pyocins suggest that they are phage tails that have evolutionarily specialized to become bacteriocins. While the data presented in this paper do not show directly that these prophage sequences act as this type of toxin, the genes of NgoФ4 encoding mainly the phage tail structural proteins could play such role.

\section{Conclusion}

To our knowledge, this is the first demonstration of bacteriophage production by the gonococcus. Their role in pathogenicity is not known and has to be understood. The activity of the repressors on the chromosomal gene activity implies strict control of the level of their production. The ability to manipulate this level could be a potential method by which bacteria regulate their growth in the human body.

\section{Methods}

Bacterial strains, plasmids, phages and growth conditions Escherichia coli Top 10: F- $m c r A \Delta(m r r-h s d R M S-m c r B C) \phi 80$

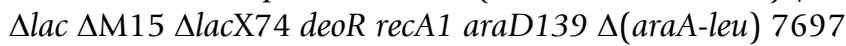


galU galK $\lambda$ s-rpsL endA1 nupG, E. coli strain MM294 $\lambda 111$ (cI857 Sam7), and E. coli $3102 \lambda$ cIts 857 were grown in Luria-Bertani broth (LB) at $37^{\circ} \mathrm{C}$ or $30^{\circ} \mathrm{C}$ [28]. Antibiotics included in media were used at the following final concentrations $\left(\mu \mathrm{gml}^{-1}\right)$ : ampicillin 100 , kanamycin 10 . Neisseria strains were grown in standardgonococcal medium (designated GCP if broth and GCK if agar) (Difco laboratories) plus Kellogg's growth supplements [29] and $0.042 \%$ sodium bicarbonate if in broth or in a $37^{\circ} \mathrm{C} \mathrm{CO}_{2}$ incubator. Haemophilus influenzae strain Rd was grown in BHI (Difco) supplemented with $2 \mu \mathrm{g}$ of NAD ml-1 and 10 $\mu \mathrm{g}$ of hemin $\mathrm{ml}^{-1}$ at $37^{\circ} \mathrm{C}$ [30]. Bacteriophage HP1 was originally obtained from R.D. Herriot. All HP1 phage manipulations were carried out as previously described [30] while those with $\lambda$ phage as described by Sambrook et al., [28]. Plasmid pUC19 was purchased from MBI Fermentas. Plasmid pXYL20 was described previously [31]. Plasmid pMPMK6 $\Omega$ was obtained from P. Mayer [24].

\section{Cloning of $\mathbf{N}$. gonorrhoeae DNA fragments carrying the Ngo $\Phi I$ and $\mathrm{Ngo} \Phi 2$ prophage genes}

A DNA fragment carrying ORF NGO0479 of $N$. gonorrhoeae FA1090 was amplified using primers RNGF1c and FNGF1CI. The resulting amplicon (717 bp) was cloned into pMPMK6 $\Omega$ at the EcoRI and the PstI sites, resulting in the formation of plasmid pMPMK6cds479. A DNA fragment carrying ORF NGO1116 of N. gonorrhoeae FA1090 was amplified using primers F2Reg8L2 and F2Reg8Rt. The resulting amplicon (711 bp) was cloned into pMPMK6 $\Omega$ and pMPMT4 $\Omega$ at the EcoRI and PstI sites, resulting in the formation of plasmids pMPMT4cds1116 and pMPMK6cds1116 respectively. A DNA fragment carrying ORF NGO0488 was amplified using primers H0488T4F and HO488T4B. The resulting amplicon (150 bp) was cloned into pMPMK6 $\Omega$ DNA into EcoRI and PstI sites, resulting in the formation of plasmid pMPMK6CDS488. All amplicons lacked their native promoters. Protein expression was from an inducible pBAD promoter.

\section{Cloning of the H. influenzae HPI phage $\mathrm{pL}$ and $\mathrm{pR}$ promoters}

The XylE cassette without any promoter sequence was derived from the plasmid pXYL20 and introduced into EcoRI and HindIII sites of pMPMK6 $\Omega$, resulting in the plasmid pMPMK6::XylE. The DNA fragments of phage HP1 carrying the $\mathrm{pL}$ and $\mathrm{pR}$ promoters [32] were amplified using HPPL-F and HPPL-R and HPPR-F and HPPR-R primers respectively. The resulting amplicons of $510 \mathrm{bp}$ and 588 bp respectively were cleaved with EcoRI and BamHI and cloned into pMPMK6::XylE plasmid, resulting in the formation of plasmids pMPMK6::XylE::pL and pMPMK6::XylE::pR respectively. In both of these plasmids the $\mathrm{pBAD}$ promoter was removed and the XylE expression placed under control of the $p \mathrm{~L}$ or $p \mathrm{R}$ promoters of HP1 phage.

\section{Detection of the prophage and phage sequences}

For testing the presence of the prophage sequences in genomic DNA, PCR reactions were carried out using Pfu polymerase (MBI Fermentas) according to the manufacturer's instructions. The reaction mixture $(25 \mu \mathrm{l})$ contained chromosomal DNA or phage DNA preparations. The reaction buffers contained: dATP, dGTP, dCTP and $\mathrm{dTTP}(0.2 \mathrm{mM}$ each $)$; forward and reverse primers $(0.2 \mu \mathrm{M}$ each); and 0.5 units of polymerase. Sequences of the primers used to amplify the chromosomal and prophage DNA and the PCR conditions are listed in Table 1. The specificity of the PCR products was confirmed by DNA sequencing the amplicons. All routine cloning procedures were carried out in accordance with protocols described in Sambrook et al. [28].

\section{Enzymes and chemicals}

Restriction enzymes were purchased from MBI Fermentas and New England Biolabs. T4 DNA ligase, Pfu DNA polymerase and DNA and protein size markers were purchased from MBI Fermentas. Kits for the DNA purification and plasmid DNA isolation were purchased from A\&A Biotechnology (Gdansk, Poland). All the chemicals used were reagent grade or better and were obtained from Sigma (St. Louis, MO), unless otherwise noted.

\section{XyIE assay}

Quantitative assays were performed as described by Braun \& Stein, [31]. Briefly, $20 \mathrm{ml}$ of LB was inoculated with an E. coli Top10 strain carrying the appropriate plasmid and grown at $37^{\circ} \mathrm{C}$ until a culture density of about $1 \times 10^{8}$ was achieved. The induction of the NGO1116 gene was achieved by the addition of arabinose to a final concentration of $0.1 \%$, with additional incubation for $60 \mathrm{~min}$ at $37^{\circ} \mathrm{C}$. Cells were harvested and resuspended in $2.5 \mathrm{ml}$ of $50 \mathrm{mM}$ potassium phosphate ( $\mathrm{pH} 7.5), 20 \mathrm{mM}$ EDTA$10 \%$ acetone (vol/vol) ( $\mathrm{pH} 7.2$ ) and $0.01 \%$ of Triton $\mathrm{X}$ 100. After $5 \mathrm{~min}$ of incubation on ice, the resulting crude lysate was clarified of cell debris by centrifugation at 4,000 $\times \mathrm{g}$ for $5 \mathrm{~min}$ and then in a microfuge at $10,000 \times \mathrm{g}$ for 10 min. Assays were performed by diluting cell extracts in assay buffer ( $100 \mathrm{mM}$ potassium phosphate, $0.2 \mathrm{mM}$ catechol). Dilutions were chosen such that a linear change in absorbance at $375 \mathrm{~nm}$ was seen over time. XylE activity was calculated by linear regression of the slope over six time points. One microunit of XylE activity corresponds to the formation of $1 \mathrm{mM}$ of 2-hydroxymuconic semialdehyde per min at $22^{\circ} \mathrm{C}$. XylE activity was normalized against total protein concentration, as determined by the method of Bradford et al. [33], with bovine serum albumin (MBI Fermentas) as the standard.

\section{Phage techniques}

The secreted form of phage and its DNA was prepared by standard phage preparation techniques [28]. Bacteria 
were collected by centrifugation from $200 \mathrm{ml}$ of exponentially growing culture in GC medium, and DNA that was extracted from the cells was dissolved in $200 \mu \mathrm{l}$ of TE buffer (10 mM Tris-HCl, $1 \mathrm{mM}$ EDTA-Na pH, 8.0). After filtration through a $0.45 \mu \mathrm{M}$ filter, the supernatant was treated for $3 \mathrm{~h}$ at $20^{\circ} \mathrm{C}$ with DNase I and RNaseA, $(25 \mu \mathrm{g}$ $\mathrm{ml}^{-1} / \mathrm{ml}$ each). Particles were precipitated by the addition of $\mathrm{NaCl}$ to a final concentration of $1 \mathrm{M}$ and polyethylene glycol 8000 to $10 \%$, incubation at $4^{\circ} \mathrm{C}$ overnight, and centrifugation at $12,000 \mathrm{~g}$ for $30 \mathrm{~min}$. DNA from the presumptive phage particles was extracted with phenol, and the precipitated material was redissolved in $200 \mu \mathrm{l}$ of TE buffer.

\section{In silico analysis}

DNA and protein sequences were compared with the GenBank and SWISS-PROT databases on the BLAST server hosted by the National Center for Biotechnology Information [34]. The N. gonorrhoeae strain FA1090 genomic sequence was obtained from the University of Oklahoma's Advanced Center for Genome Technology [35] and the N. meningitidis strain Z2491 (serogroup A) genomic sequence (and the genomic sequence of the $N$. meningitidis strain FAM 18 from the Sanger Institute [36]. Other comparisons were performed using the BLAST tools at the NCBI web site [34]. Codon usage and codon frequency comparisons were performed using the CUSP and CODCMP programs at [37]. The $\mathrm{G}+\mathrm{C}$ content of various chromosomal fragments was determined using the program COMPOSITION at [38]. ORFs were identified using GeneMark.hmm for PROKARYITIC (Version2.4) [39], EMBOSS [37], Glimmer [40], EasyGene 1.0 [41], ORF Finder[42], NCBI Conserved Domain Search [34], GeneImage Map for Neisseria gonorrhoeae [17], and EMBL-EBI (CpG content) [43]).

\section{Electron microscopy}

An overnight culture of $N$. gonorrhoeae was diluted 30 times in fresh media and incubated with shaking for $2 \mathrm{hr}$. Mitomycin $\mathrm{C}$ was added (20 ng ml-1 final concentration) and culture incubated in the dark for $3 \mathrm{hr}$. Chloroform was added and the culture shaken for $20 \mathrm{~min}$. The cells and debris were removed by centrifugation for $20 \mathrm{~min}$ at $5000 \mathrm{rpm}$ and the supernatant was filtrated through a $0.45 \mu \mathrm{m}$. Phage particles were precipitated by the addition of $\mathrm{NaCl}$ to a final concentration of $1 \mu \mathrm{M}$ and polyethylene glycol 8000 to $10 \%$, in the presence of $\mathrm{CaCl}_{2}$ to a final concentration of $1 \mathrm{mM}$ and DNase I and RNaseA, $(25 \mu \mathrm{g}$ $\mathrm{ml}^{-1}$ each) for $16 \mathrm{~h}$ at $4^{\circ} \mathrm{C}$. The precipitate was centrifuged for $30 \mathrm{~min}$ at $12500 \mathrm{rpm}$ at $4^{\circ} \mathrm{C}$. The pellet was resuspended in TE buffer. Phage were stained with uranyl acetate $(2 \%)$ for $30 \mathrm{sec}$ prior to visualization on a Zeiss EM10CA microscope (80 kv).

\section{Authors' contributions}

AK participated in the molecular and phage biology experiments participated in the sequence alignment. MAP performed the sequence alignments. MM participated in the molecular and phage biology experiments. TKM performed the electron microscopy. AP helped conceive the study, participated in the design of the study, participated in the molecular and phage biology experiments, participated in the sequence alignment, and participated in the drafting of the manuscript participated drafted the manuscript. DCS helped conceive the study, participated in the design of the study and participated in the drafting of the manuscript. All authors have read and approve this manuscript.

\section{Acknowledgements}

This work was supported by the Faculty of Biology Grant no. 501/64-1055/ 4 to AP, and a grant from the National Institutes of Health (AI24452) to DCS. We acknowledge the Gonococcal Genome Sequencing Project supported by USPHS/NIH grant \#Al38399, and B.A. Roe, L. Song, S. P. Lin, X. Yuan, S. Clifton, Tom Ducey, Lisa Lewis and D.W. Dyer at the University of Oklahoma.

\section{References}

I. Brussow H, Canchaya C, Hardt WD: Phages and the evolution of bacterial pathogens: from genomic rearrangements to lysogenic conversion. Microbiol Mol Biol Rev 2004, 68:560-602.

2. Canchaya $C$, Fournous $G$, Brussow $H$ : The impact of prophages on bacterial chromosomes. Mol Microbiol 2004, 53:9-18.

3. Casjens S: Prophages and bacterial genomics: what have we learned so far? Mol Microbiol 2003, 49:277-300.

4. Waldor MK, Friedman DI: Phage regulatory circuits and virulence gene expression. Curr Opin Microbiol 2005, 8:459-465.

5. Groisman EA, Casadesus ]: The origin and evolution of human pathogens. Mol Microbiol 2005, 56:1-7.

6. Casjens SR: Comparative genomics and evolution of the tailed-bacteriophages. Curr Opin Microbiol 2005, 8:45I-458.

7. Tinsley CR, Bille E, Nassif X: Bacteriophages and pathogenicity: more than just providing a toxin? Microbes Infect 2006, 8: $1365-137 \mid$.

8. Steinberg VI, Hart EJ, Handley J, Goldberg ID: Isolation and characterization of a bacteriophage specific for Neisseria perflava. J Clin Microbiol 1976, 4:87-9I.

9. Stone RL, Culbertson CG, Powell HM: Studies of a bacteriophage active against a chromogenic Neisseria. J Bacteriol 1956, 71:516-520.

10. Phelps LN: Isolation and characterization of bacteriophages for Neisseria. J Gen Virol 1967, I:529-536.

II. Cary SG, Hunter DH: Isolation of bacteriophages active against Neisseria meningitidis. J Virol 1967, 1:538-542.

12. Campbell LA, Short HB, Young FE, Clark VL: Autoplaquing in Neisseria gonorrhoeae. J Bacteriol 1985, 164:46I-465.

13. Klee SR, Nassif X, Kusecek B, Merker P, Beretti JL, Achtman M, Tinsley CR: Molecular and biological analysis of eight genetic islands that distinguish Neisseria meningitidis from the closely related pathogen Neisseria gonorrhoeae. Infect Immun 2000, 68:2082-2095.

14. Morgan GJ, Hatfull GF, Casjens S, Hendrix RW: Bacteriophage Mu genome sequence: analysis and comparison with Mu-like prophages in Haemophilus, Neisseria and Deinococcus. J Mol Biol 2002, 317:337-359.

15. Masignani V, Giuliani MM, Tettelin H, Comanducci M, Rappuoli R, Scarlato V: Mu-like Prophage in serogroup B Neisseria meningitidis coding for surface-exposed antigens. Infect Immun 200I, 69:2580-2588.

16. Bille E, Zahar JR, Perrin A, Morelle S, Kriz P, Jolley KA, Maiden MC, Dervin C, Nassif $X$, Tinsley CR: A chromosomally integrated 
bacteriophage in invasive meningococci. J Exp Med 2005, 20I:1905-1913.

17. Los Alamos National Laboratory Bioscience Division [http:/ /stdgen.northwestern.edu/]

18. Kawai M, Uchiyama I, Kobayashi I: Genome Comparison In Silico in Neisseria Suggests Integration of Filamentous Bacteriophages by their Own Transposase. DNA Res 2005, I 2:389-40 I.

19. Tsuchimoto S, Ohtsubo H, Ohtsubo E: Two genes, pemK and peml, responsible for stable maintenance of resistance plasmid RI 00. J Bacteriol 1988, I70:|46|-|466.

20. Zhang J, Zhang Y, Zhu L, Suzuki M, Inouye M: Interference of mRNA function by sequence-specific endoribonuclease PemK. J Biol Chem 2004, 279:20678-20684.

21. Abeles AL, Friedman SA, Austin SJ: Partition of unit-copy miniplasmids to daughter cells. III. The DNA sequence and functional organization of the PI partition region. J Mol Biol 1985, 185:26I-272.

22. Nakayama K, Takashima K, Ishihara H, Shinomiya T, Kageyama M, Kanaya S, Ohnishi M, Murata T, Mori H, Hayashi T: The R-type pyocin of Pseudomonas aeruginosa is related to $\mathrm{P} 2$ phage, and the F-type is related to lambda phage. Mol Microbiol 2000, 38:213-23I.

23. Chen Y, Golding I, Sawai S, Guo L, Cox EC: Population fitness and the regulation of Escherichia coli genes by bacterial viruses. PLoS Biol 2005, 3:e229.

24. Mayer MP: A new set of useful cloning and expression vectors derived from pBlueScript. Gene 1995, 163:4 I-46.

25. Young I, Wang I, Roof WD: Phages will out: strategies of host cell lysis. Trends Microbiol 2000, 8: $120-128$.

26. Breyen SA, Dworkin M: Autoplaquing in Myxococcus strains. J Bacteriol 1984, I 58: I 163-I I64.

27. Wagner PL, Waldor MK: Bacteriophage control of bacterial virulence. Infect Immun 2002, 70:3985-3993.

28. Sambrook J, Fritsch EF, Maniatis T: Molecular Cloning: a laboratory manual 2nd edition. Cold Spring Harbor, NY: Cold Spring Harbor Laboratory Press; 1989.

29. White LA, Kellogg DS Jr: Neisseria gonorrhoeae identification in direct smears by a fluorescent antibody counterstain method. Appl Microbiol 1965, 13: I7I-I74.

30. Barcak G], Chandler MS, Redfield RJ, Tomb JF: Genetic systems in Haemophilus influenzae. Methods Enzymol 1991, 204:321-342.

31. Braun DC, Stein DC: The IgtABCDE gene cluster, involved in lipooligosaccharide biosynthesis in Neisseria gonorrhoeae, contains multiple promoter sequences. J Bacteriol 2004, 186:1038-1049.

32. Esposito D, Fitzmaurice WP, Benjamin RC, Goodman SD, Waldman AS, Scocca J]: The complete nucleotide sequence of bacteriophage HPI DNA. Nucleic Acids Res 1996, 24:2360-2368.

33. Bradford MM: A rapid and sensitive method for the quantitation of microgram quantities of protein utilizing the principle of protein-dye binding. Anal Biochem 1976, 72:248-254.

34. National Center for Biotechnology Information [http:// www.ncbi.nlm.nih.gov]

35. University of Oklahoma's Advanced Center for Genome Technology [http://www.genome.ou.edu]

36. Sanger Institute [http://www.sanger.ac.uk]

37. EMBOSS tools [http://www.ebi.ac.uk]

38. On line analysis tools [http://molbiol-tools.ca]

39. GeneMark [http://exon.gatech.edu]

40. Glimmer microbial gene finder system [http://cbcb.umd.edu/ software/glimmer/]

4l. Easy Gene [http://www.cbs.dtu.dk]

42. ORF finder [http://myhits.isb-sib.ch]

43. GC content [http://www.ebi.ac.uk]

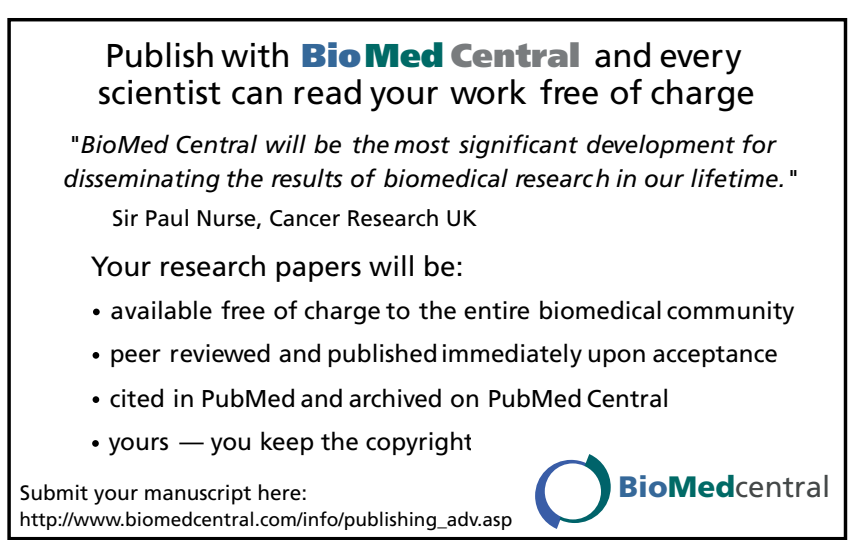

